\title{
Groundwater quality assessment for domestic and agriculture purposes in Puducherry region
}

\author{
M. Sridharan ${ }^{1}$ (D) D. Senthil Nathan ${ }^{1}$
}

Received: 12 July 2016/ Accepted: 14 March 2017/Published online: 27 March 2017

(c) The Author(s) 2017. This article is an open access publication

\begin{abstract}
Totally about 174 groundwater samples have been collected during pre-monsoon and post-monsoon season to study the suitability for domestic and agriculture purposes along the coastal aquifers of Puducherry region. Parameters such as $\mathrm{pH}$, total dissolved solids (TDS), electrical conductivity (EC), sodium $(\mathrm{Na})$, potassium $(\mathrm{K})$, calcium $(\mathrm{Ca})$, magnesium $(\mathrm{Mg})$, bicarbonate $\left(\mathrm{HCO}_{3}\right)$, chloride $(\mathrm{Cl})$ and sulfate $\left(\mathrm{SO}_{4}\right)$ were analyzed to assess the suitability of groundwater for domestic purposes. Sodium adsorption ratio (SAR), magnesium adsorption ratio (MAR), residual sodium bicarbonate (RSC), soluble sodium percentage ( $\mathrm{Na} \%)$, permeability index (PI) and chlorinity index were assessed for irrigation purposes. The higher concentration of ions such as $\mathrm{Na}, \mathrm{Ca}, \mathrm{Cl}$ and $\mathrm{So}_{4}$ indicates seawater intrusion, mineral dissolution, intense agricultural practices and improper sewage disposal. The level of EC, TDS and hardness in the water samples indicates that maximum of them are suitable for drinking and domestic purposes. The parameters such as SAR, $\mathrm{Na} \%$, PI, MAR and Chlorinity index indicates that majority of water sample are very good to moderately suitable for agriculture. In pre-monsoon, RSC of about $5.7 \%$ of samples was higher which when used for a longer time alter the soil properties and reduce crop production. Wilcox diagram suggests that water samples are of medium saline to low sodium type indicating that groundwater is suitable for irrigation. Temporal variation of groundwater quality shows significant increasing trend in $\mathrm{EC}$, TDS and ions like $\mathrm{Mg}, \mathrm{K}$ and $\mathrm{Cl}$ in the last decade, mainly due to anthropogenic activities with little geogenic impact in the quality of groundwater.
\end{abstract}

M. Sridharan

msridharansri@gmail.com

1 Department of Earth Sciences, Pondicherry University, Puducherry 605014, India
Keywords Groundwater · Puducherry · Domestic . Agriculture $\cdot$ Seawater intrusion $\cdot$ Wilcox

\section{Introduction}

Water is the basic need without which life does not exist in the earth. It is well known that major portion of the earth is occupied by water, out of it only few amounts are fresh water and meant for drinking and other purposes like agriculture, industries, etc. Water occurs in the earth in different forms like surface water, groundwater, glaciers and seawater. Among which the groundwater serves the majority of purposes where there are no other sources. The coasts are one such region which solely depends on groundwater for all its needs. Groundwater quality is affected by both geogenic and anthropogenic agents (Sheikhy Narany et al. 2014). The quality of groundwater is at greater risk due to seawater intrusion along the coast all around the world (Batayneh et al. 2014; Mondal et al. 2010). Groundwater salinization is also due to overpumping, population growth, high evaporation rate and less recharge, seawater-freshwater interaction (Sheikhy Narany et al. 2014). The chemical, physical and biological characteristics of groundwater vary spatially and temporally. Soil or rock water interaction while recharging and discharging processes, mineral dissolution, fossil water, etc. are the processes governing hydrochemistry (Hem 1985). The fertilizers, pesticides and other chemical products used for agriculture also affect the groundwater quality (Nag and Lahiri 2012). Several authors have reported about the quality of groundwater worldwide (Batayneh et al. 2014; Senthilkumar et al. 2014; Kazemi and Mohammadi 2012; Kumar et al. 2015; Krishna Kumar et al. 2011; 
Nwankwoala et al. 2012). The groundwater studies were carried out in Puducherry region by Public Works Department (2007), Thilagavathi et al. 2012, Nathan et al. 2012, CGWB 1993, Chidambaram et al. 2011 and Pethaperumal et al. 2010. Puducherry is a union territory where there is tremendous increase in population, urbanization, industrialization recent days equivalent to metropolitan city. In addition, the study area is a tourist spot where a large number of people visit throughout the year leading to increase in demand for drinking water and water for domestic purposes. This situation prevailing in study area urged me to study the impacts of all above factors on quality of groundwater.

\section{Study area}

Puducherry is a union territory which lies along the southern east coast of Indian sub-continent whose Latitudes are $11^{\circ} 45^{\prime}$ and $12^{\circ} 03^{\prime} \mathrm{N}$ and Longitudes are $79^{\circ} 37^{\prime}$ and $79^{\circ} 53^{\prime} \mathrm{E}$ (Fig. 1). The average area of Puducherry region is about $293 \mathrm{sq}$. km. The study area receives its mean rainfall of about $1272.7 \mathrm{~m}$ from northeast monsoon. The rivers Gingee and Ponaiyar are the two major rivers flow off in the study area. This region depends on the groundwater for all basic activities as the rivers of this area yield water during monsoon period only (CGWB 2007).

\section{Geology of the study area}

The Puducherry region has undulations in ground ranging from 30 to $100 \mathrm{~m}$ with mean ascent of $15 \mathrm{~m}$ above mean sea level (CGWB 2007). The major lithological variations found in this region are 1. Coastal plain, 2. Alluvial plain and 3. Uplands. The type of soil in the study area is dominated by Red, Black, Alluvial and Colluvial soil (CGWB 2007).

The study area is bounded by Quaternary, Tertiary and Mesozoic sediments whose age ranges from Archean to recent. The two major aquifers are Cuddalore sandstone and Vanur sandstone formations (CGWB 2007; Fig. 2). Groundwater from the above-mentioned formations are available in confined and semi-confined aquifers conditions which are explored by means of bore wells, dug wells and open wells (Thilagavathi et al. 2012).

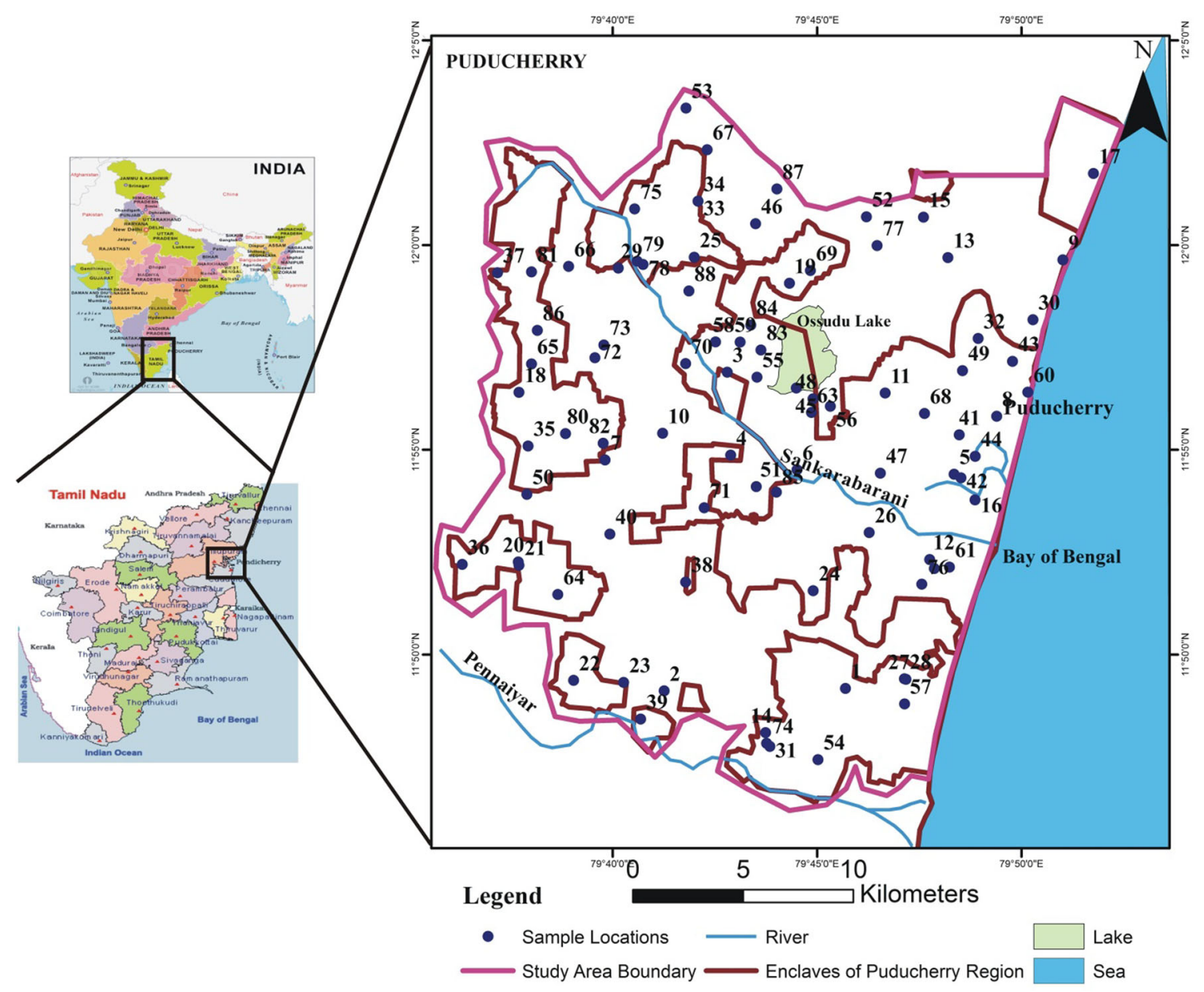

Fig. 1 Study area map with sample locations 


\section{Methodology}

Totally 175 representative groundwater samples were collected (Fig. 1) from bore wells of the study area during premonsoon and post-monsoon of the year 2014. Water samples are collected in polythene containers which are washed using MilliQ water and then by water to be sampled prior to sampling. The samples are collected after pumping the wells for about $10-15 \mathrm{~min}$ and filtered as per standard APHA procedure (John and Dickerson 1993). pH, Electrical conductivity (EC), Salinity, and Total Dissolved solids are measured onsite using Systronics Water

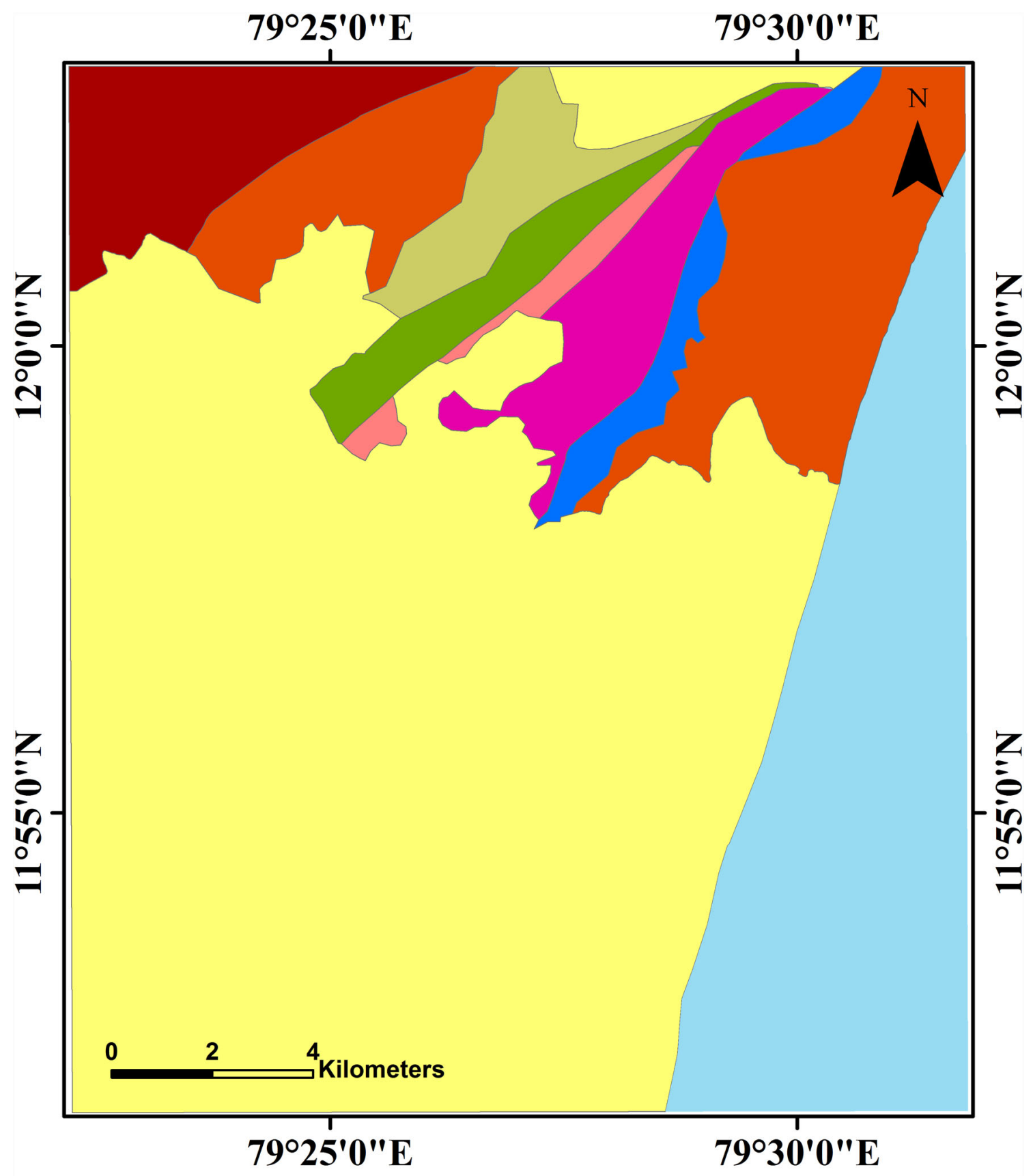

Legend

$\begin{array}{lll}\text { Bay of Bengal } & \text { Cuddalore Formation } & \text { Ottai Formation } \\ \square \text { Alluvium } & \text { Kadaperikuppam Formation } & \text { Turuvai Formation } \\ \square \text { Charnockite } & \text { Manaveli Formation } & \text { Vanur Formation }\end{array}$

Fig. 2 Geological map of Puducherry region 
Analyzer124. The collected water samples are brought to the laboratory and measured for chemical parameters like anions - chloride $(\mathrm{Cl})$, bicarbonate $\left(\mathrm{HCO}_{3}\right)$, sulfate $\left(\mathrm{SO}_{4}{ }^{-}\right)$ and cations like sodium $(\mathrm{Na})$, potassium $(\mathrm{K})$, calcium $(\mathrm{Ca})$ and magnesium $(\mathrm{Mg})$. Ions such $\mathrm{Na}, \mathrm{K}, \mathrm{Ca}, \mathrm{Mg}, \mathrm{Cl}$ and $\mathrm{SO}_{4}{ }^{-}$were analyzed using ion chromatography (ICS1100) and bicarbonate using volumetric titration method (Sulfuric acid method). Quality of the data analyzed was done by analyzing blanks, standards and duplicates in between the sample analysis. The ionic percentage error was $\pm 10 \%$.

To study the temporal variation in groundwater quality of the study area, water quality data have been collected from Water Testing Laboratory, Public Health Division (PWD), Puducherry for the year 2004 and 2008 for which the complete dataset is available. The water quality data collected include $\mathrm{pH}, \mathrm{EC}$, TDS, $\mathrm{Na}, \mathrm{K}, \mathrm{Ca}, \mathrm{Mg}$ and $\mathrm{Cl}$. The average rainfall and water quality data of the year 2004 and 2008 have been tabulated in the Table 7.

Table 1 Chemical analysis results of water samples for pre- and post-monsoon season

\begin{tabular}{|c|c|c|c|c|}
\hline \multirow[t]{2}{*}{ Parameters } & \multicolumn{2}{|c|}{ Pre-monsoon } & \multicolumn{2}{|c|}{ Post-monsoon } \\
\hline & Max & Min & Max & Min \\
\hline $\mathrm{pH}$ & 8.56 & 5.99 & 7.45 & 6.09 \\
\hline TDS (mg/L) & 6380 & 173 & 3980 & 110 \\
\hline $\mathrm{EC}(\mu \mathrm{S} / \mathrm{cm})$ & 3080 & 341 & 3980 & 110 \\
\hline $\mathrm{Na}(\mathrm{mg} / \mathrm{L})$ & 3588 & 26.2 & 5201 & 120 \\
\hline $\mathrm{K}(\mathrm{mg} / \mathrm{L})$ & 353 & ND & 417 & ND \\
\hline $\mathrm{Ca}(\mathrm{mg} / \mathrm{L})$ & 881 & ND & 1683 & 63 \\
\hline $\mathrm{Mg}(\mathrm{mg} / \mathrm{L})$ & 719 & 7 & 524 & 7.4 \\
\hline $\mathrm{Cl}(\mathrm{mg} / \mathrm{L})$ & 470 & 8 & 2351 & 35.4 \\
\hline $\mathrm{SO}_{4}(\mathrm{mg} / \mathrm{L})$ & 948 & ND & 414 & ND \\
\hline $\mathrm{HCO}_{3}(\mathrm{mg} / \mathrm{L})$ & 902 & ND & 317 & ND \\
\hline MAR & 100 & 10.9 & 387 & 13.8 \\
\hline Hardness & 353 & 5.9 & 220 & 80 \\
\hline
\end{tabular}

\section{Results and discussion}

Using the above methodology, the groundwater samples have been collected and analyzed for different parameters to evaluate the quality of groundwater for domestic and agriculture purposes. The results obtained are discussed in Table 1.

\section{Drinking water quality}

Water is one of the major pathways for the diseases to acquire human body. For a sound mind and healthy body, water that we intake has to be in a good condition. By nature, water is composed of ions, dissolved gases and unicellular organisms. When these ions, dissolved gases and harmful organisms exceeds a certain limit water is said to be unfitfor drinking and other domestic purposes. This limit for individual parameters has been fixed based on its effect when itfis excess or less in concentration as suggested by World Health Organization (WHO 2004) and Bureau of Indian standards (Table 2).

\section{$\mathrm{pH}$}

The acidic and alkaline properties of water can be studied to evaluate the interaction of water with rock or other material interacting with it (Hem 1985). The permissible limit for $\mathrm{pH}$ as prescribed by global and Indian bureau standards for drinking water is 6.5-8.5 (WHO 2004 and BIS 2012). The $\mathrm{pH}$ in the collected samples of the study area ranges between 5.99 and 8.5 in pre-monsoon (Table 1; Fig. 3a) and between 6.09 and 7.45 in postmonsoon (Table 1; Fig. 3b).

\section{Electrical conductivity (EC)}

The conductance of water increases with increase in concentration of ions dissolved in water (Hem 1985). In the

Table 2 Comparison of groundwater samples with BIS and WHO standards

\begin{tabular}{|c|c|c|c|c|c|c|}
\hline \multirow[t]{2}{*}{ Parameter } & \multicolumn{2}{|c|}{ Bureau of Indian standards } & \multicolumn{2}{|c|}{ World Health Organization Standard } & \multicolumn{2}{|c|}{$\%$ of Samples above Maximum Permissible limit } \\
\hline & $\begin{array}{l}\text { Highest desirable } \\
\text { limit }\end{array}$ & $\begin{array}{l}\text { Maximum } \\
\text { permissible limit }\end{array}$ & $\begin{array}{l}\text { Highest } \\
\text { desirable limit }\end{array}$ & $\begin{array}{l}\text { Maximum } \\
\text { permissible limit }\end{array}$ & Pre-monsoon & Post-monsoon \\
\hline $\mathrm{pH}$ & $6.5-8.5$ & $6.5-9.2$ & $6.5-8.5$ & $6.5-9.2$ & Nil & Nil \\
\hline $\mathrm{EC}(\mu \mathrm{S} / \mathrm{cm})$ & 1500 & 3000 & 1500 & 3000 & 1.2 & 1.1 \\
\hline TDS (mg/L) & 500 & 1000 & 500 & 1000 & 5.7 & 9 \\
\hline $\mathrm{Na}(\mathrm{mg} / \mathrm{L})$ & - & - & - & 300 & Nil & Nil \\
\hline $\mathrm{K}(\mathrm{mg} / \mathrm{L})$ & - & - & - & 10 & Nil & Nil \\
\hline $\mathrm{Ca}(\mathrm{mg} / \mathrm{L})$ & 75 & 200 & 75 & 200 & 17 & 53 \\
\hline $\mathrm{Mg}(\mathrm{mg} / \mathrm{L})$ & 30 & 100 & 50 & 100 & 11 & 19 \\
\hline $\mathrm{Cl}(\mathrm{mg} / \mathrm{L})$ & 250 & 1000 & 200 & 600 & 17 & 3 \\
\hline $\mathrm{SO}_{4}(\mathrm{mg} / \mathrm{L})$ & 200 & 400 & 200 & 400 & 17 & 25 \\
\hline
\end{tabular}




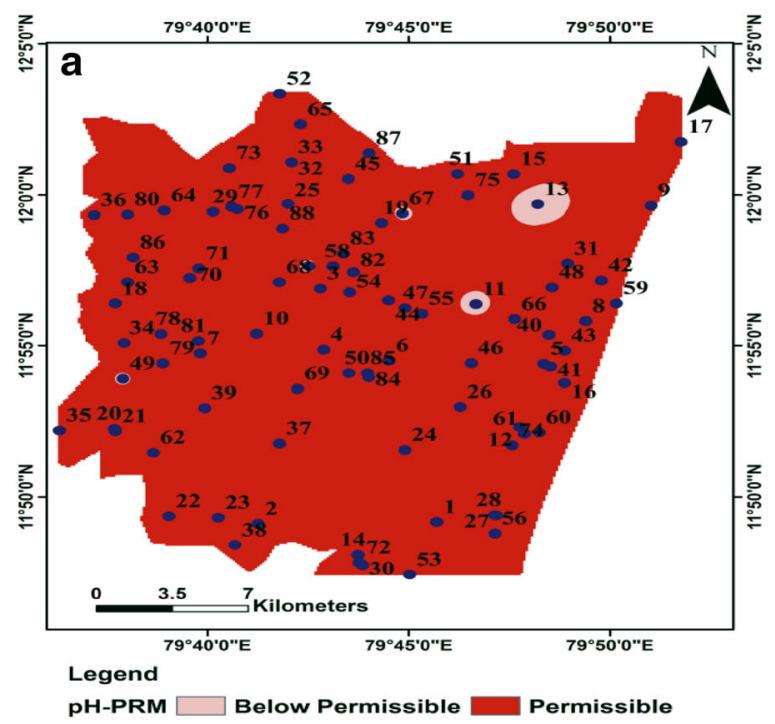

Fig. 3 a, b Spatial distribution map of $\mathrm{pH}$ (pre- and post-monsoon)

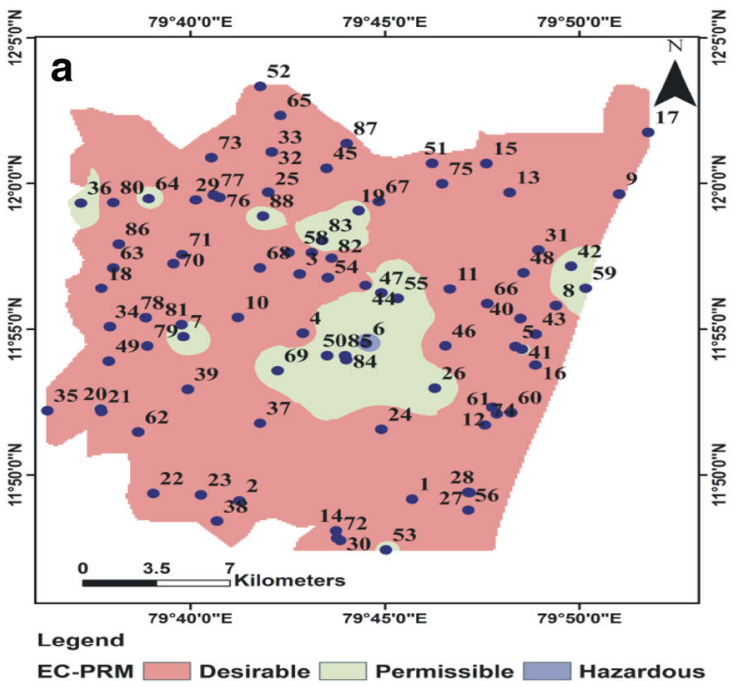

Fig. 4 a, b Spatial Distribution map of EC (pre- and post-monsoon)

study area, EC measured ranges from 341 to $3080 \mu$ mhos/ $\mathrm{cm}$ and 259 to $3980 \mu \mathrm{mhos} / \mathrm{cm}$ in post-monsoon and premonsoon, respectively (Table 1; Fig. 4a, b). The WHO and BIS standard for EC is $1400 \mu \mathrm{mhos} / \mathrm{cm}$ (WHO, 2004 and BIS 2012). The 73.3 and $79.3 \%$ of groundwater samples are less than $1400 \mu \mathrm{mhos} / \mathrm{cm}$ in pre- and post-monsoon respectively, indicating type- 1 where the salt enrichment is low. Totally, 25.6 and $13.8 \%$ of samples EC were in medium range between 1400 and $3000 \mu \mathrm{mhos} / \mathrm{cm}$ in premonsoon and post-monsoon respectively, falling in type- 2 category indicating medium salt enrichment (Sarath Prasanth et al. 2012). And 1.2 and $1.1 \%$ of pre- and postmonsoon samples fall under type-3 indicating very high salt enrichment. Samples falling under type-2 and type-3
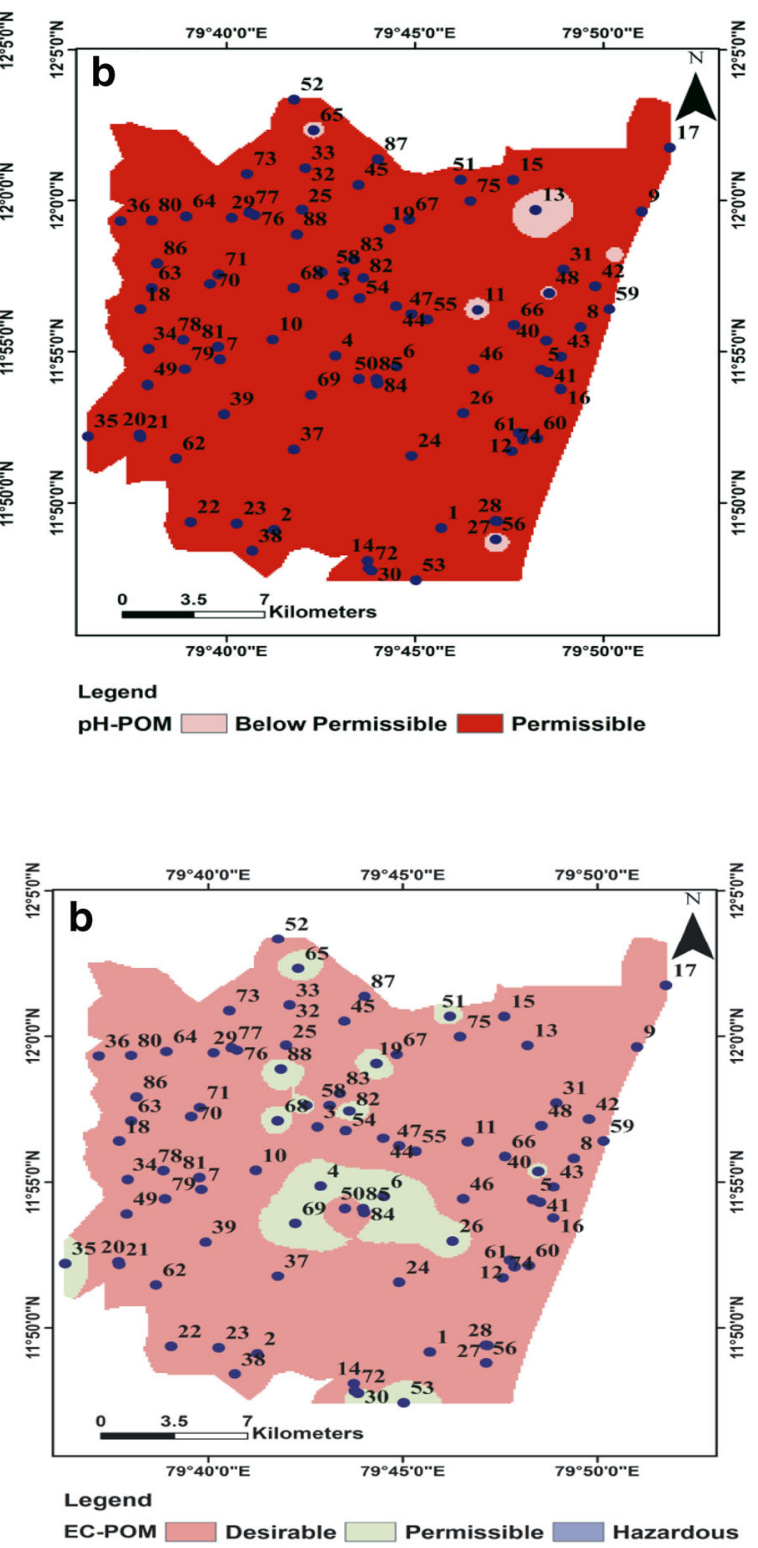

category show that medium to high enrichment of salts with higher EC may be due to seawater intrusion, effect of $\mathrm{pH}$ and intense long-term agricultural practices in the area of study (Sarath Prasanth et al. 2012; Ramesh et al. 2012).

\section{Total dissolved solids (TDS)}

Based on TDS, the groundwater suitability for various purposes has been classified as in Table 3. About 94 and $90 \%$ of groundwater samples are suitable for drinking; 5 and $9 \%$ of samples were under permissible limits for drinking; 1 and $9 \%$ of samples were suitable for agriculture in pre- and post-monsoon respectively (David et al. 1966). The permissible level for TDS in groundwater is $1000 \mathrm{mg} /$ 
Table 3 Classification of groundwater based on TDS (Davis and DeWiest 1966)

\begin{tabular}{lccl}
\hline TDS $(\mathrm{mg} / \mathrm{L})$ & $\%$ of samples & Purpose \\
\cline { 2 - 3 } & Pre-monsoon & Post-monsoon & \\
\hline$<500$ & 94 & 90 & Drinking \\
$500-1000$ & 5 & 9 & Permissible for drinking \\
$>1000$ & 1 & 9 & Suits for agriculture \\
$>1,00,000$ & Nil & Nil & Unsuitable \\
\hline
\end{tabular}

L as suggested by WHO and BIS standards for water samples (WHO, 2004 and BIS, 2012). 94.3 and 91\% of samples were within the limit of water quality standard in pre-monsoon and post-monsoon respectively. 5.7 and 9\% of samples were above the permissible level and not suitable for drinking purposes. TDS varies from 173 to $6380 \mathrm{mg} / \mathrm{L}$ in pre-monsoon (Table 1; Fig. 5a) and from 237 to $2320 \mathrm{mg} / \mathrm{L}$ in post-monsoon (Table 1; Fig. $5 b$ ). Higher Total Dissolved solids content may be due to improper sewage disposal, lesser $\mathrm{pH}$ with higher mineral dissolution, seawater intrusion (Sarath Prasanth et al. 2012; Subba Rao 2001); (Ramesh et al. 2012).

\section{Total hardness}

The percolating rainwater into the ground is acidic due to the presence of $\mathrm{CO}_{2}$ in atmosphere and roots of the plants in soil. This low $\mathrm{pH}$ solution dissolves the insoluble carbonates and its impurities such as sulfates, chlorides, silicates, etc. into the groundwater making the groundwater harder. Water with higher hardness are not suitable for domestic and industrial purposes (Sarath Prasanth et al.
2012); (Gopinath et al. 2015); (Tahlawi et al. 2016); (Nag and Lahiri 2012).

The total hardness for water samples was determined using the expression (Todd 1980):

Total hardness $=2.5 \mathrm{Ca}+4.1 \mathrm{Mg}$

where the concentration of calcium and magnesium is expressed in meq/L.

The total hardness of the water samples ranges from 5 to 353 and 13 to $387 \mathrm{mg} / \mathrm{L}$ in both the seasons (Table 4; Table 1; Fig. 13a, b). According to Sawyer and McCarty, 1967, the water samples have been classified as soft, moderately hard, hard and very hard as mentioned in the table above. Among the water samples collected, 2 and $1 \%$ of water samples are harder in pre- and post-monsoon. Idayanchavadi, Mannadipet and Aryankuppam are the locations showing high hardness above the permissible limit. Most of the water samples of the area of study were soft with hardness less than $75 \mathrm{mg} / \mathrm{L}$.

\section{Sodium and potassium ( $\mathrm{Na}$ and $\mathrm{K})$}

The maximum permissible limit for sodium in groundwater is $200 \mathrm{mg} / \mathrm{L}$ as per WHO and BIS standard. The concentration of sodium above permissible level leads to salty taste and health hazards like blood pressure, kidney stones, arteriosclerosis, edema and hyperosmolarity (Sarath Prasanth et al. 2012); (Ramesh and Elango 2011). The concentration of sodium varied from 2.62 to 358 and 12 to $520 \mathrm{mg} / \mathrm{L}$ in pre-monsoon and post-monsoon respectively, in the area of interest (Table 1; Fig. 6a, b). Manadipet and Pudukuppam are the locations where concentration of sodium is higher than the prescribed standards both in pre-
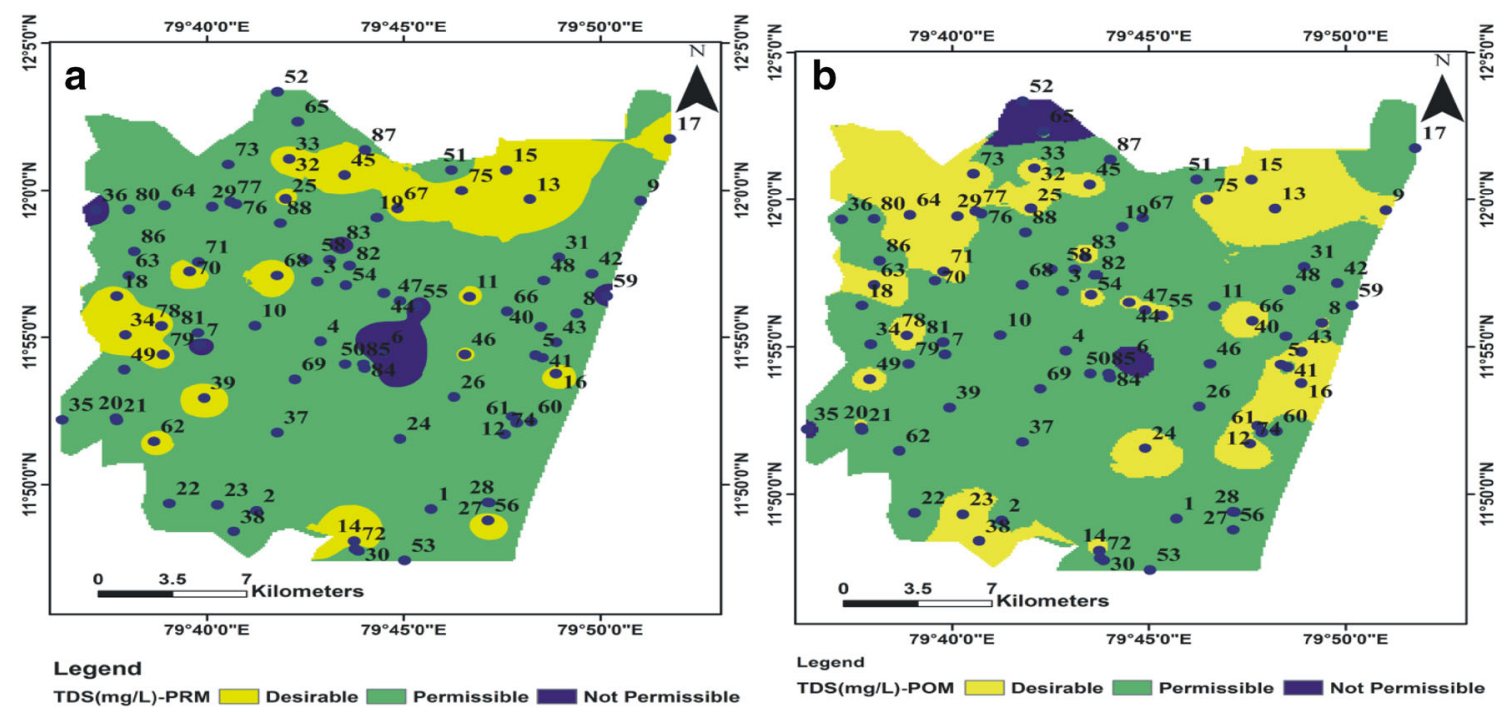

Fig. 5 a, b Spatial distribution map of TDS (pre- and post-monsoon) 
Table 4 Classification of groundwater based on total hardness (mg/ L) (Sawyer and McCarty 1967)

\begin{tabular}{llll}
\hline $\begin{array}{l}\text { Total } \\
\text { hardness } \\
(\mathrm{mg} / \mathrm{l})\end{array}$ & $\begin{array}{l}\text { Type of } \\
\text { water }\end{array}$ & $\begin{array}{l}\text { Number of samples } \\
\text { percentage pre- } \\
\text { monsoon }\end{array}$ & $\begin{array}{l}\text { Number of samples } \\
\text { percentage post- } \\
\text { monsoon }\end{array}$ \\
\hline$<75$ & Soft & 93 & 97 \\
$75-150$ & $\begin{array}{l}\text { Moderately } \\
\text { high }\end{array}$ & 5 & 2 \\
$150-300$ & $\begin{array}{l}\text { Hard } \\
>300\end{array}$ & 2 & 1 \\
\hline
\end{tabular}

monsoon and post-monsoon, respectively. The geogenic means include dissolution from rocks like rhyolite, shale and evaporite sediments (Hem 1985).

Potassium is generally very low in groundwater samples and there is no separate permissible limit for it. It ranges from not detectable to $39 \mathrm{mg} / \mathrm{L}$ and not detectable to $41 \mathrm{mg} / \mathrm{L}$ in both pre-monsoon and post-monsoon respectively (Table 1; Fig. 7a, b).

\section{Calcium and magnesium $\left(\mathrm{Ca}^{2+}\right.$ and $\left.\mathrm{Mg}^{2+}\right)$}

The maximum permissible level for calcium in groundwater is $75 \mathrm{mg} / \mathrm{L}$ as per WHO and BIS standards for groundwater. It ranges from not detectable to 88.6 and 6.3 to $168 \mathrm{mg} / \mathrm{L}$ in pre-monsoon and post-monsoon season (Table 1; Fig. 8a, b) of the study site. Mannadipet in premonsoon and Anandapuram in post-monsoon are the two locations exceeding the permissible limit. In sedimentary terrain like study area, it occurs as carbonates in rocks like limestone and as cementing material in sandstone (Hem 1985). Moreover, the study site is covered entirely by sedimentary lithounits enriched in sandstone and limestone

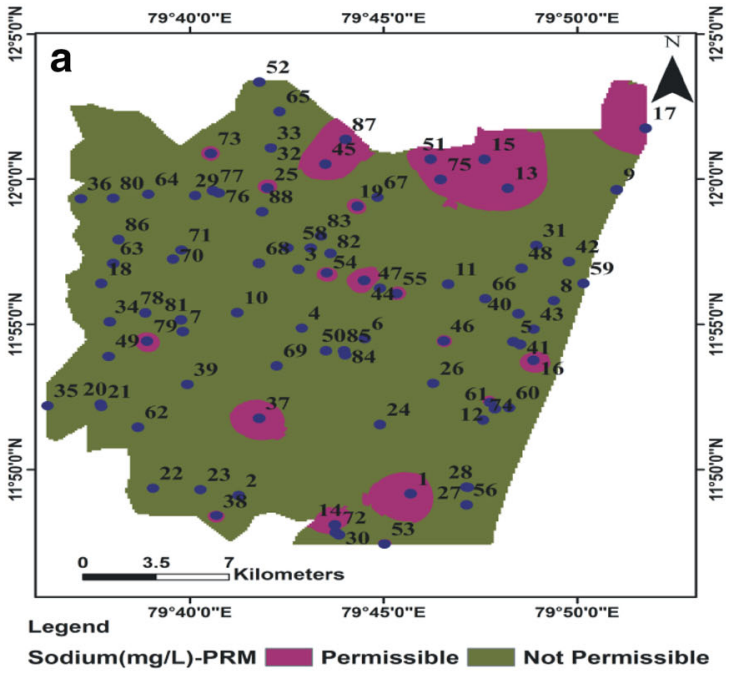

Fig. 6 a, b Spatial distribution map of $\mathrm{Na}$ (pre- and post-monsoon)
(CGWB 2007); (Herman 1978); (Basavarajappa and Manjunatha 2015). It reaches the groundwater by ion exchange processes (Annapoorna and Janardhana 2015).

Magnesium is commonly found in ferromagnesian minerals in igneous rocks and as carbonates in sedimentary rocks. The standard limit for magnesium in groundwater suggested by WHO and BIS is $30 \mathrm{mg} / \mathrm{L}$. The magnesium concentration ranges from 7 to 719 and 7 to $524 \mathrm{mg} / \mathrm{L}$ in pre-monsoon and post-monsoon respectively (Table 1; Fig. 9a, b). In both the seasons, most of the samples exceeded the permissible level. Excess magnesium may lead to unpleasant taste (Ramesh and Elango 2011) and encrustation on water supplies (BIS 2009).

\section{Chloride $\left(\mathrm{Cl}^{-}\right)$}

The desirable level for chloride in groundwater is $250 \mathrm{mg} /$ $\mathrm{L}$ and maximum permissible level is $1000 \mathrm{mg} / \mathrm{L} . \mathrm{Cl}^{-}$ion varies from 8.7 to 4707 and 35 to $2351 \mathrm{mg} / \mathrm{L}$ in pre- and post-monsoon respectively (Table 1; Fig. 10a, b). The excess concentration of chloride in study area indicates mainly seawater intrusion and industrial waste disposal.

\section{Sulfate $\left(\mathrm{SO}_{4}{ }^{-}\right)$}

The desirable level for sulfate in groundwater is $200 \mathrm{mg} / \mathrm{L}$ as maximum permissible level is $400 \mathrm{mg} / \mathrm{L}$ as suggested by WHO and BSI. The sulfate concentration varied from 8.7 to $470 \mathrm{mg} / \mathrm{L}$ and not detectable to $414 \mathrm{mg} / \mathrm{L}$ in both preand post-monsoon respectively (Table 1; Fig. 11a, b). Sulfate in groundwater might be due to the presence of sulphide-bearing minerals and gypsum in aquifer materials, application of sulfate-rich fertilizers and industrial wastes.

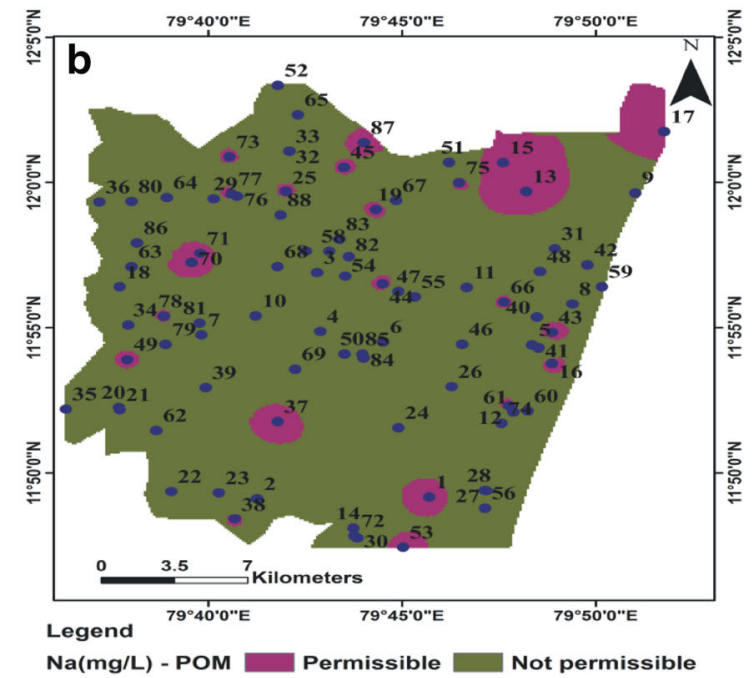




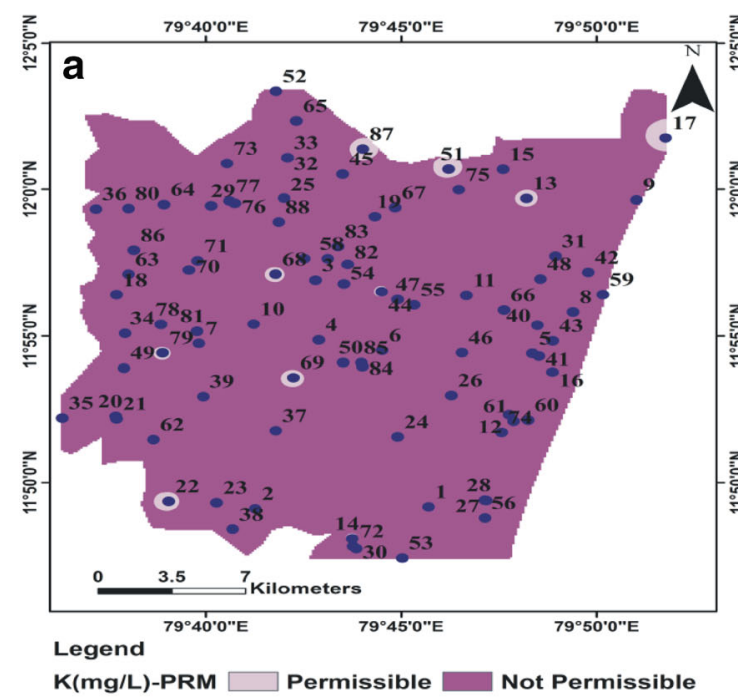

Fig. 7 a, b Spatial distribution map of $\mathrm{K}$ (pre- and post-monsoon)

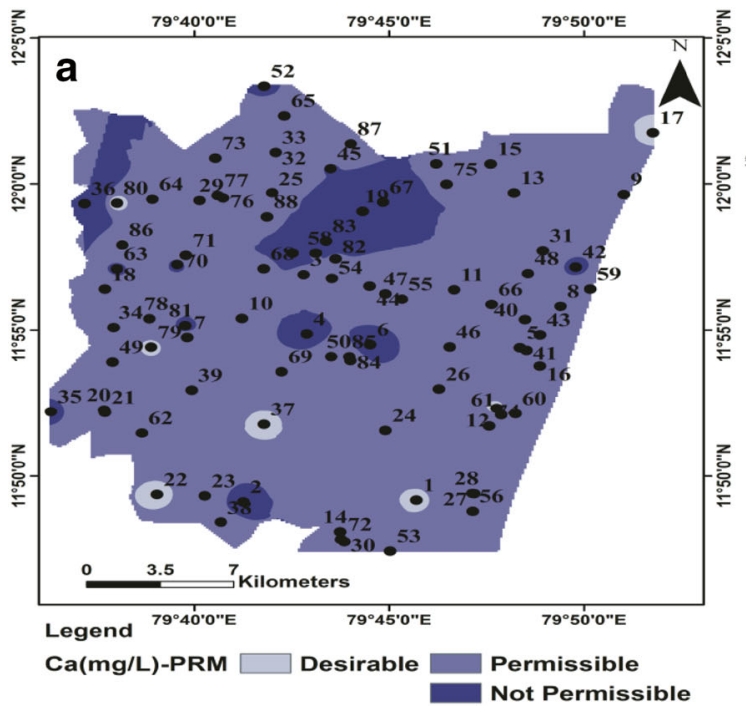

Fig. 8 a, b Spatial distribution map of $\mathrm{Ca}$ (pre- and post-monsoon)

\section{Bicarbonate $\left(\mathrm{HCO}_{3}{ }^{-}\right)$}

The bicarbonate concentration in the study site ranges from not detectable to $902 \mathrm{mg} / \mathrm{L}$ and not detectable to $317.2 \mathrm{mg} /$ $\mathrm{L}$ in pre- and post-monsoon season respectively (Table 1; Fig. 12a, b). The dominance of bicarbonate ion indicates mineral dissolution process.

\section{Irrigation water quality}

For a plant growth apart from soil type and quality, water is also an essential component. Poor quality water when used for agriculture purposes may affect the crop productivity (Iqbal et al. 2012). Intense agricultural practices and

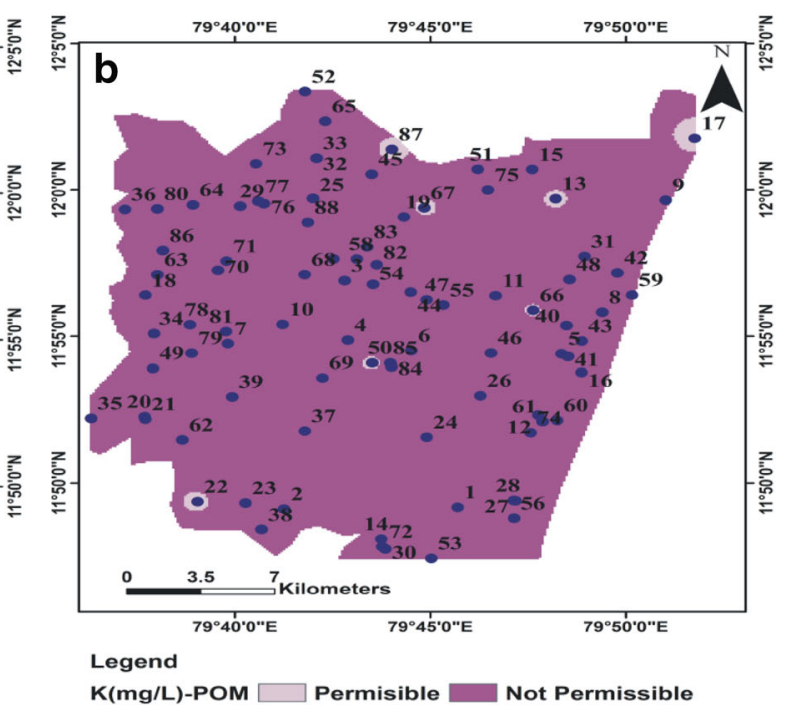

K(mg/L)-POM $\square$ Permisible $\square$ Not Permissible

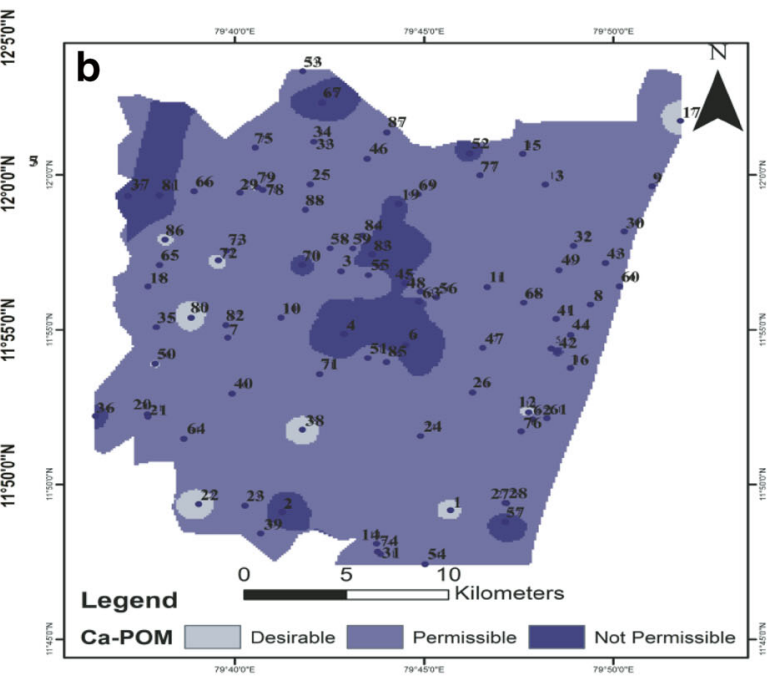

application of chemical fertilizers, pesticides and insecticides have significant effect on groundwater quality. Sodium adsorption ratio (SAR), soluble sodium percentage (Na\%), permeability index(PI), magnesium adsorption ratio(MAR) and salinity hazard are some of the factors to understand the groundwater suitability for agriculture.

\section{Sodium adsorption ratio}

Sodium adsorption ratio or sodicity is the measure of relative concentration of sodium with respect to calcium and magnesium in groundwater (Haritash et al. 2014; Iqbal et al. 2012). The SAR is calculated using the following equation (Richards et al. 1954): 

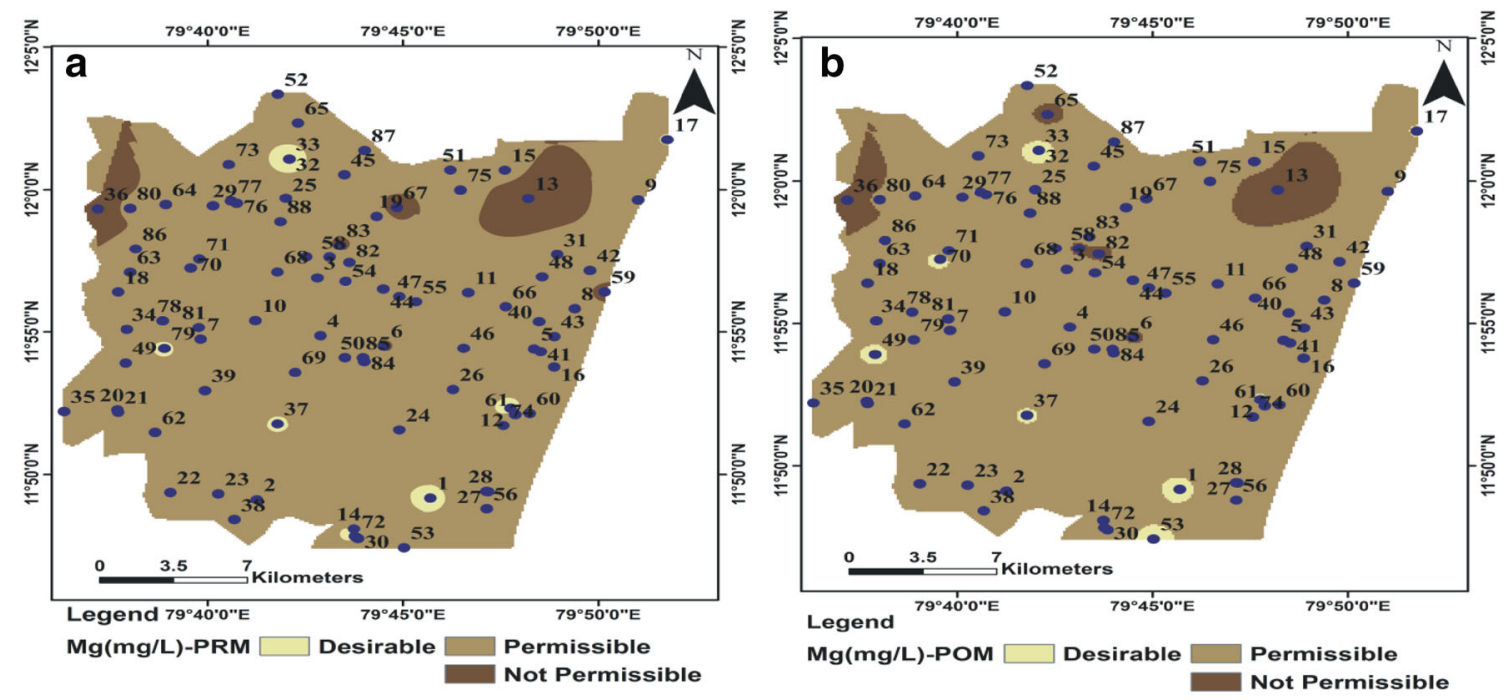

Fig. 9 a, b Spatial distribution map of $\mathrm{Mg}$ (pre- and post-monsoon)

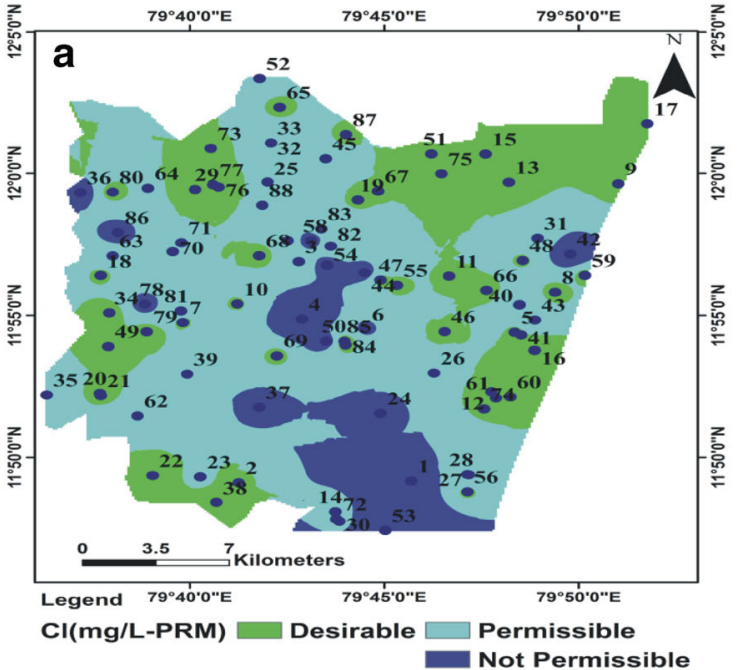

Fig. 10 a, b Spatial distribution map of $\mathrm{Cl}$ (pre- and post-monsoon)

$$
\mathrm{SAR}=\mathrm{Na} / \sqrt{ }((\mathrm{Ca}+\mathrm{Mg}) / 2)
$$

Concentration of calcium and magnesium are in meq/ L.

The classifications of groundwater sample based on SAR are mentioned in the Table 5. According to it, the samples are grouped as excellent, good, permissible and unsuitable for agriculture purposes. About $92 \%$ of samples in pre-monsoon and $83 \%$ of groundwater samples in postmonsoon season are suitable for agriculture, respectively. 1 and $2.2 \%$ of samples in pre- and post-monsoon are not suitable for agriculture purpose, respectively. The calculated data were then plotted on Wilcox diagram (Sodium Hazard (SAR) Vs. Electrical conductivity) as shown in Fig. 15. From Fig. 15, it is inferred that majority of samples in pre-monsoon falls under C3S1 (highly saline-low

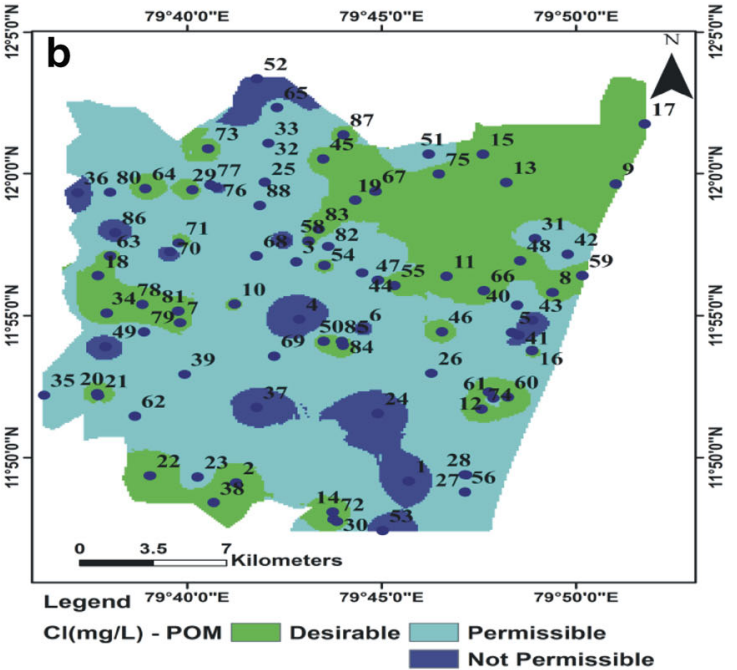

sodic type) and C3S2 (Highly Saline-medium sodic type) category. In post-monsoon, the samples are distributed almost equally under $\mathrm{C} 2 \mathrm{~S} 1$ (medium saline-low sodic hazard), C3S1 (highly saline-low sodic type), C3S2 (Highly Saline-medium sodic type) and C2S2 (medium saline-medium sodic type) category. Finally, the above plot indicates that in the study area groundwater are of medium saline and low sodium type in both the seasons except in few places. About 1 and $2.2 \%$ of samples in pre- and postmonsoon fall under very high sodium and very high salinity type which are not suitable for agriculture because of high sodium concentration in the groundwater. High salinity and high sodium type of water leads to high osmotic pressure and eventually it leads to reduction in water absorption by roots of plant (Ramesh and Elango 

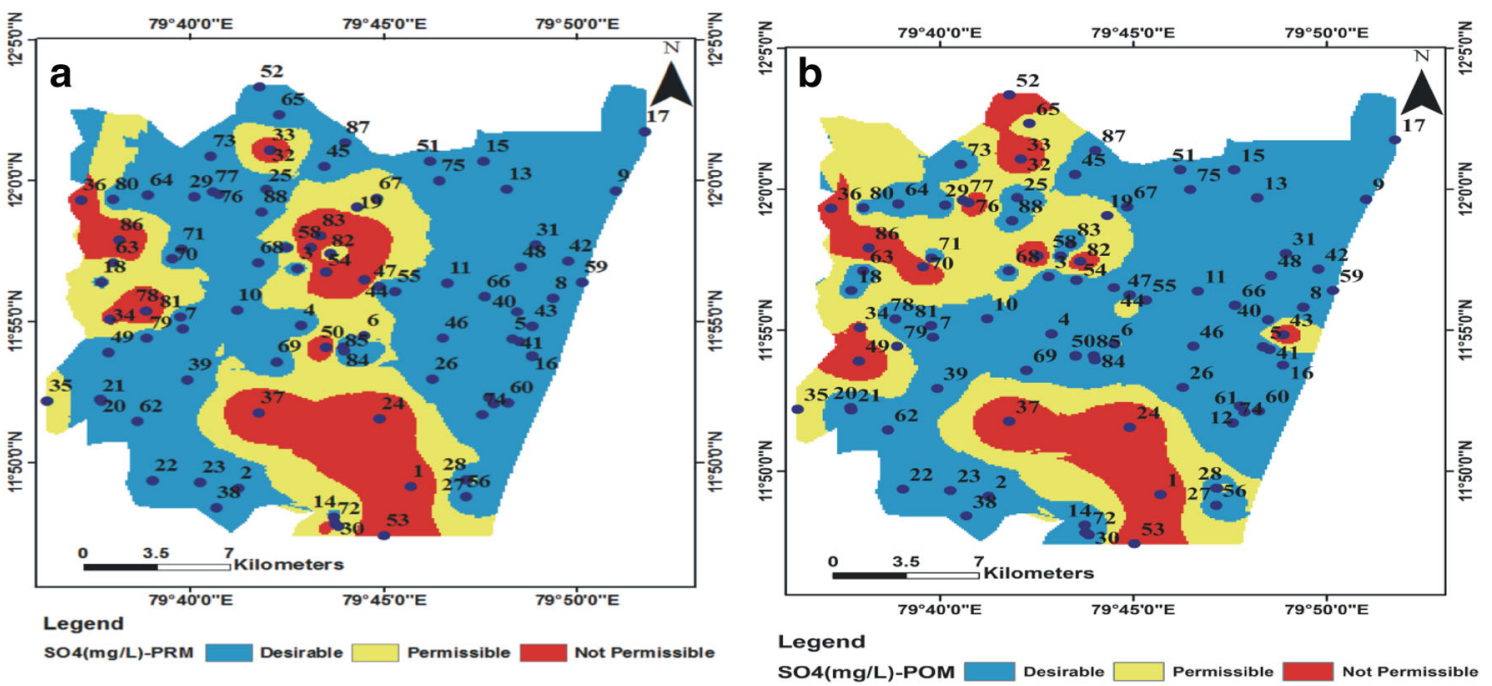

Fig. 11 a, b Spatial distribution map of SO4 (pre- and post-monsoon)
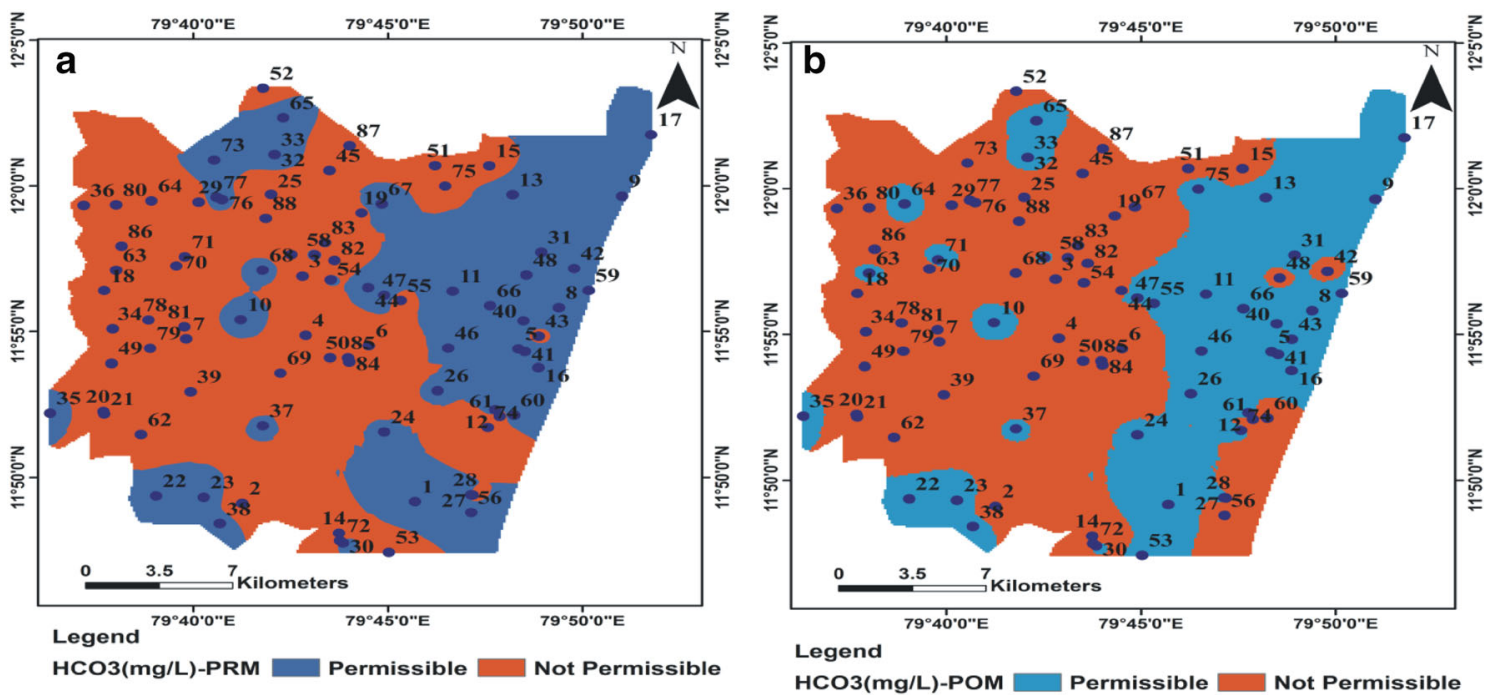

Fig. 12 a, b Spatial distribution map of $\mathrm{HCO}_{3}$ (pre- and post-monsoon)

Table 5 Classification of groundwater based on SAR (Todd 1980; Richards 1954)

\begin{tabular}{llll}
\hline SAR & $\begin{array}{l}\text { Suitability } \\
\text { for irrigation }\end{array}$ & $\begin{array}{l}\text { Number of samples } \\
\text { percentage pre- } \\
\text { monsoon }\end{array}$ & $\begin{array}{l}\text { Number of samples } \\
\text { percentage-Post- } \\
\text { monsoon }\end{array}$ \\
\hline $0-10$ & Excellent & 92 & 83 \\
$10-18$ & Good & 6.8 & 13.5 \\
$18-26$ & Permissible & 1 & 1.1 \\
$>26$ & Unsuitable & 1 & 2.2 \\
\hline
\end{tabular}

2011; Brindha and Elango 2011). Kakayantopu and Pudukuppam are the locations showing high SAR $>26$ which are unsuitable for agriculture.

\section{Residual sodium carbonate (RSC)}

The suitability of groundwater is affected by excess concentration of bicarbonates and carbonates over calcium and magnesium. The excess bicarbonate concentration is harmful to physical properties of soil (Das and Nag 2015). The RSC can be calculated by the following formula (Eaton 1950):

$\mathrm{RSC}=\left(\mathrm{HCO}_{3}^{-}+\mathrm{CO}_{3}^{-}\right)-\left(\mathrm{Ca}^{2+}+\mathrm{Mg}^{2+}\right)$

where the concentration of ions is expressed in meq/L.

In the study area, 94.3 and $98.9 \%$ of samples in pre- and post-monsoon RSC is $<1.25$ indicating that those samples are suitable for agriculture. $1.1 \%$ of both pre- and post- 

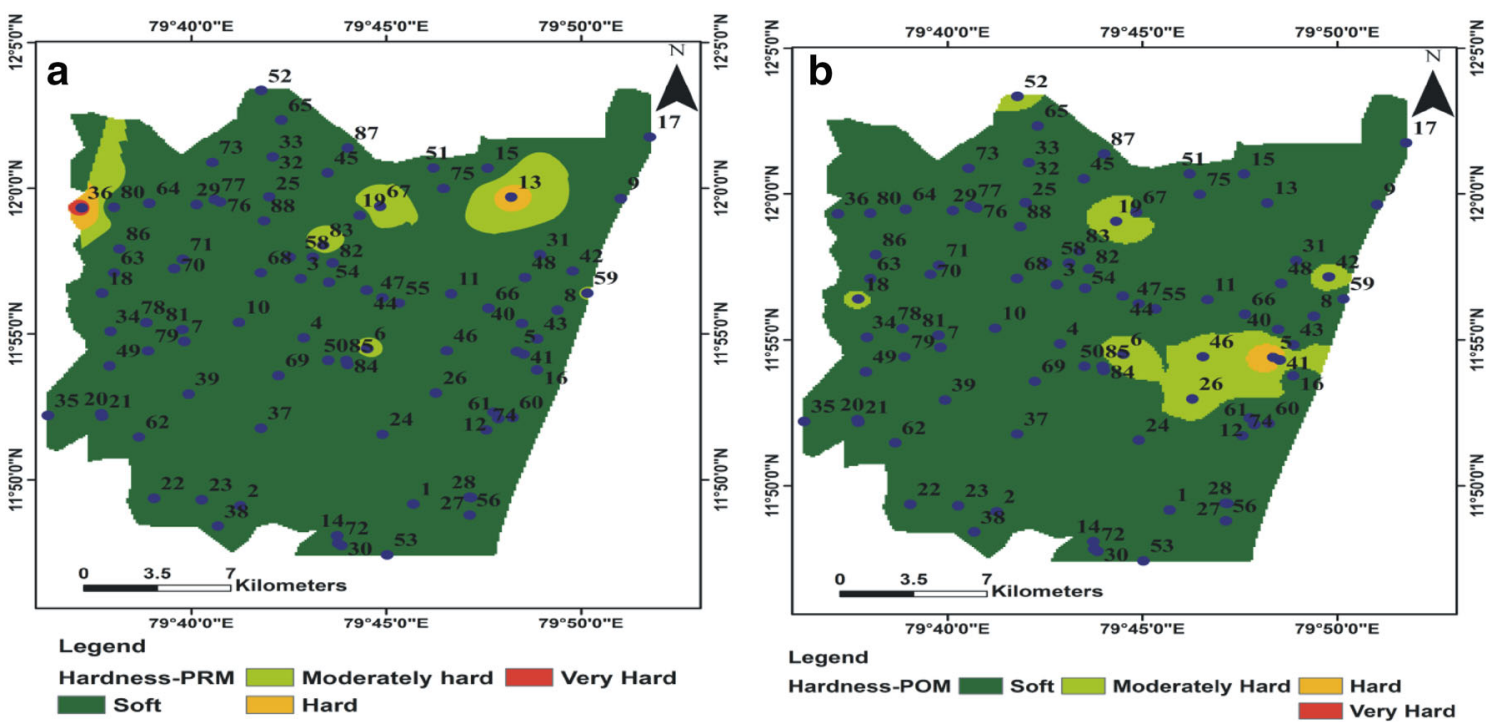

Fig. 13 a, b Spatial distribution map of hardness (pre- and post-monsoon)

Table 6 Classification of groundwater for agriculture based on RSC

RSC Suitability Number of samples Number of samples for percentage pre- percentage postIrrigation monsoon monsoon

\begin{tabular}{llrr}
\hline$<1.25$ & Low & 94.3 & 98.9 \\
$1.25-2.5$ & Medium & 1.1 & 1.1 \\
$>2.5$ & High & 5.7 & Nil
\end{tabular}

monsoon season are moderately suitable for agriculture with RSC of $<2.5$. $5.7 \%$ in pre-monsoon are not suitable for agriculture as shown in the (Table 6; Fig. 16) whose RSC are of $>2.5$. Kariamanickam, Soriyankuppam, Tavalakuppam, Thirubhuvanai, Tirukanur and Vadanur are the locations showing RSC $>2.5$ indicating alkaline hazard and non-suitability of water for agriculture.

\section{Soluble sodium percentage $(\mathrm{Na} \%)$}

Sodium concentration in excess reduces the permeability of soil, destroys the soil structure and affects the drainage of the area which eventually leads to reduction of crop production and plant growth (Iqbal et al. 2012). Na\% is calculated using the formula (Eaton 1950).

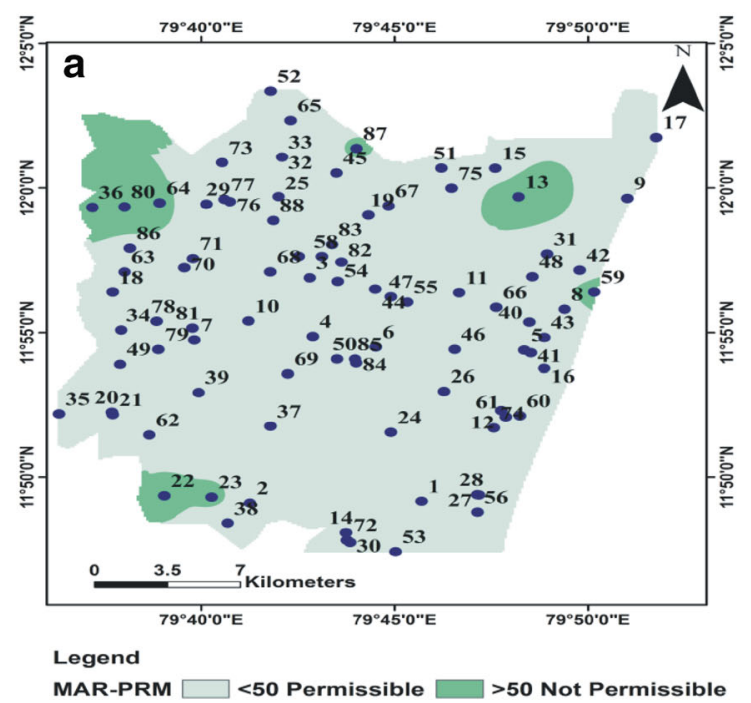

Fig. 14 a, b Spatial distribution map of MAR (pre- and post-monsoon)

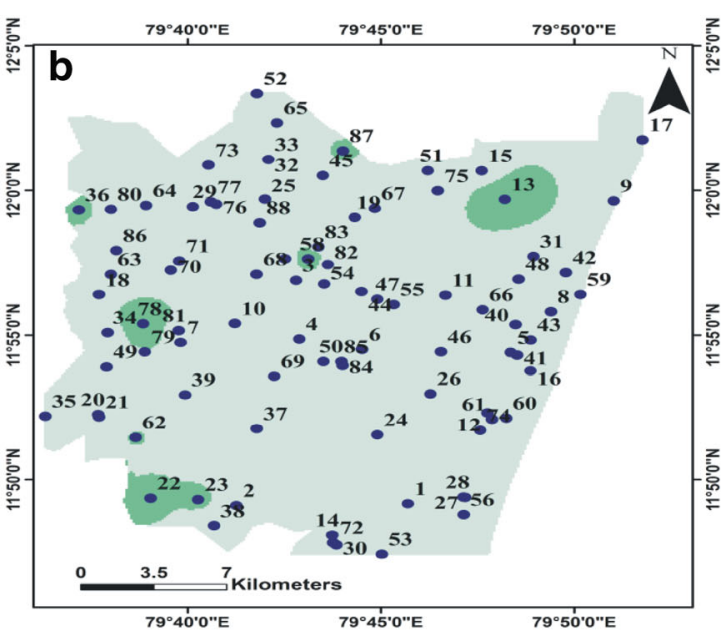

Legend

MAR-POM $\square<50$ Permissible $\square>50$ Not Permissible 


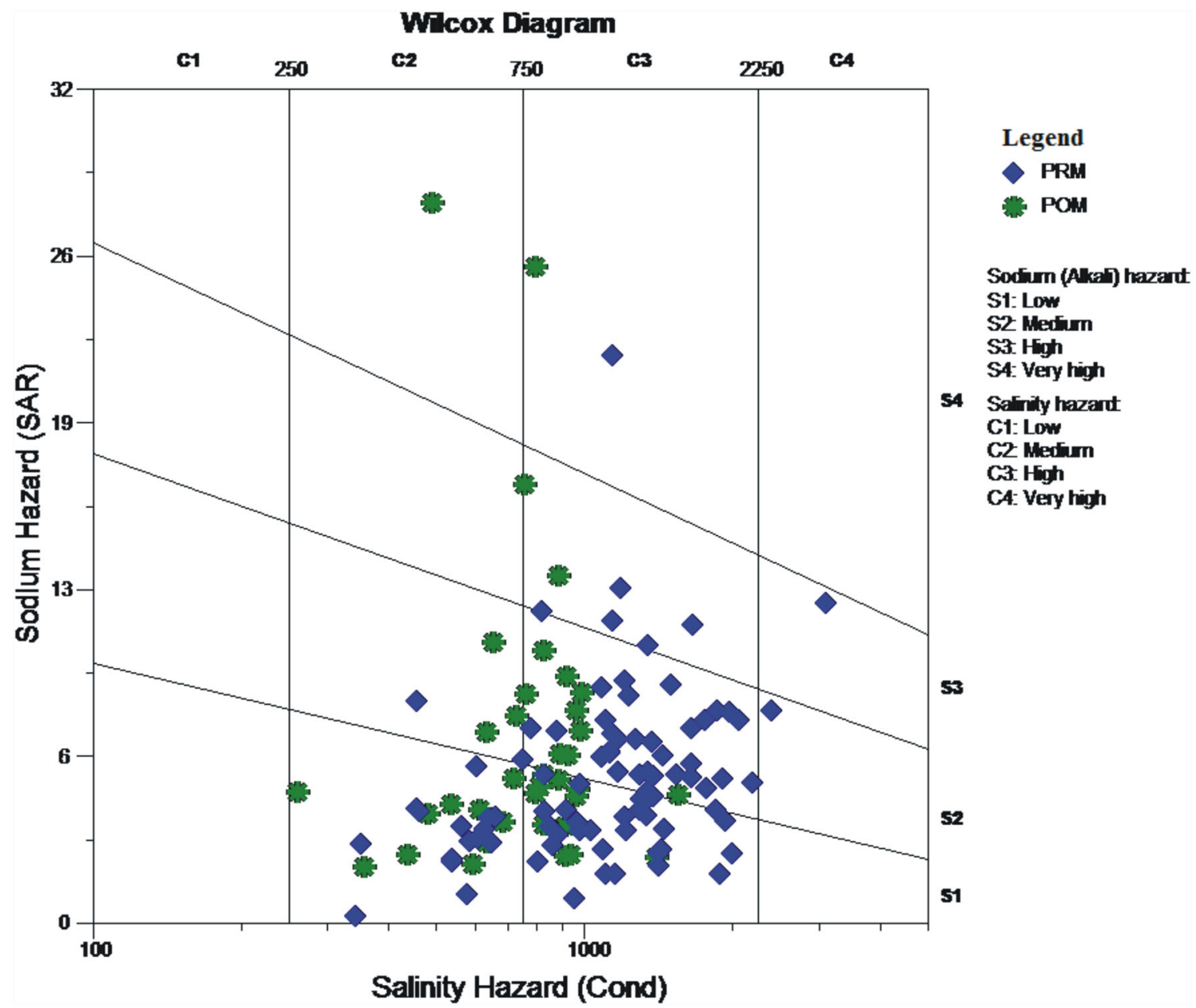

Fig. 15 Classification of irrigation water based on sodium hazard and salinity hazard

Fig. 16 RSC for groundwater samples

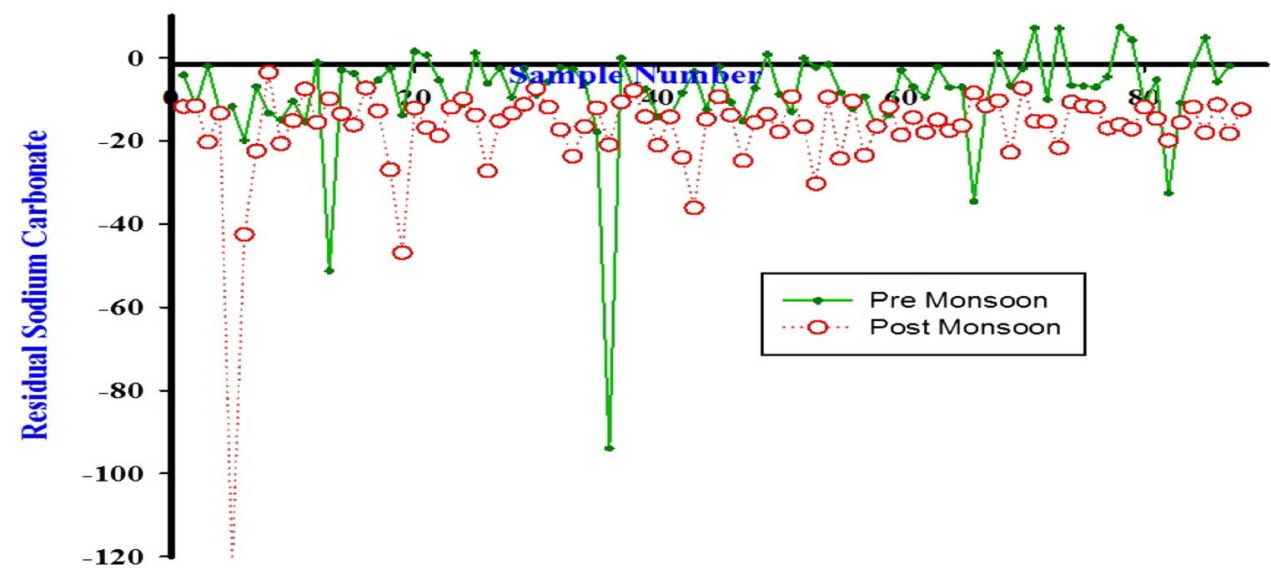

$\mathrm{Na} \%=[(\mathrm{Na}+\mathrm{K}) /(\mathrm{Ca}+\mathrm{Mg}+\mathrm{Na}+\mathrm{K})] \times 100$

The concentration of ions is expressed in meq/L. Based on $\mathrm{Na} \%$ with respect to $\mathrm{EC}$, the groundwater samples have been classified (Wilcox 1955) as shown in Fig. 17. About 82.7 and $78 \%$ of samples in the study area range from good to permissible level for agriculture in pre- and post-monsoon respectively. 16 and $16.8 \%$ of samples are doubtful to not suitable for agriculture purposes. The location Pudukuppam in pre-monsoon shows very high $\mathrm{Na} \%$ indicating nonsuitability of groundwater for agriculture. 
Fig. 17 Wilcox diagram

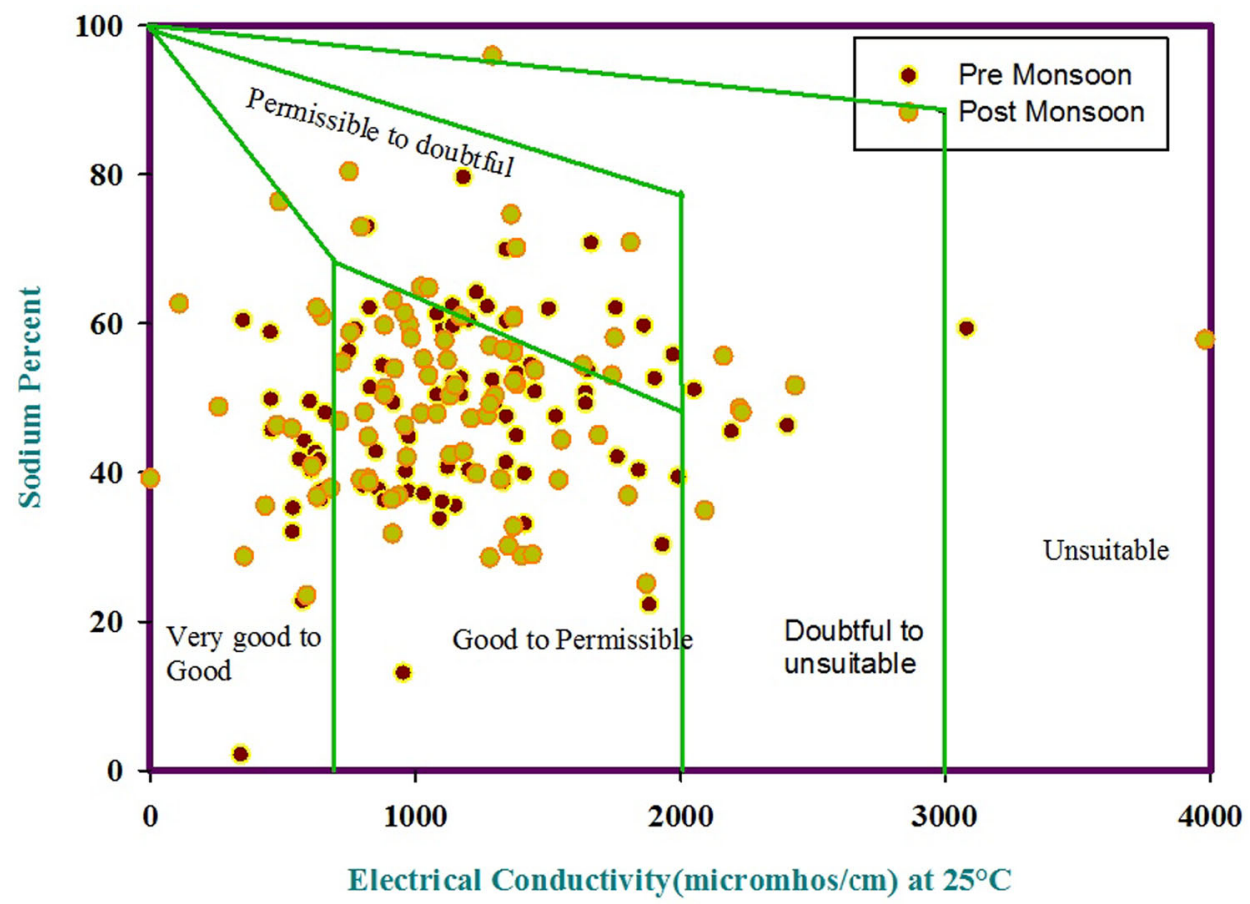

Fig. 18 Donneen's chart for permeability index

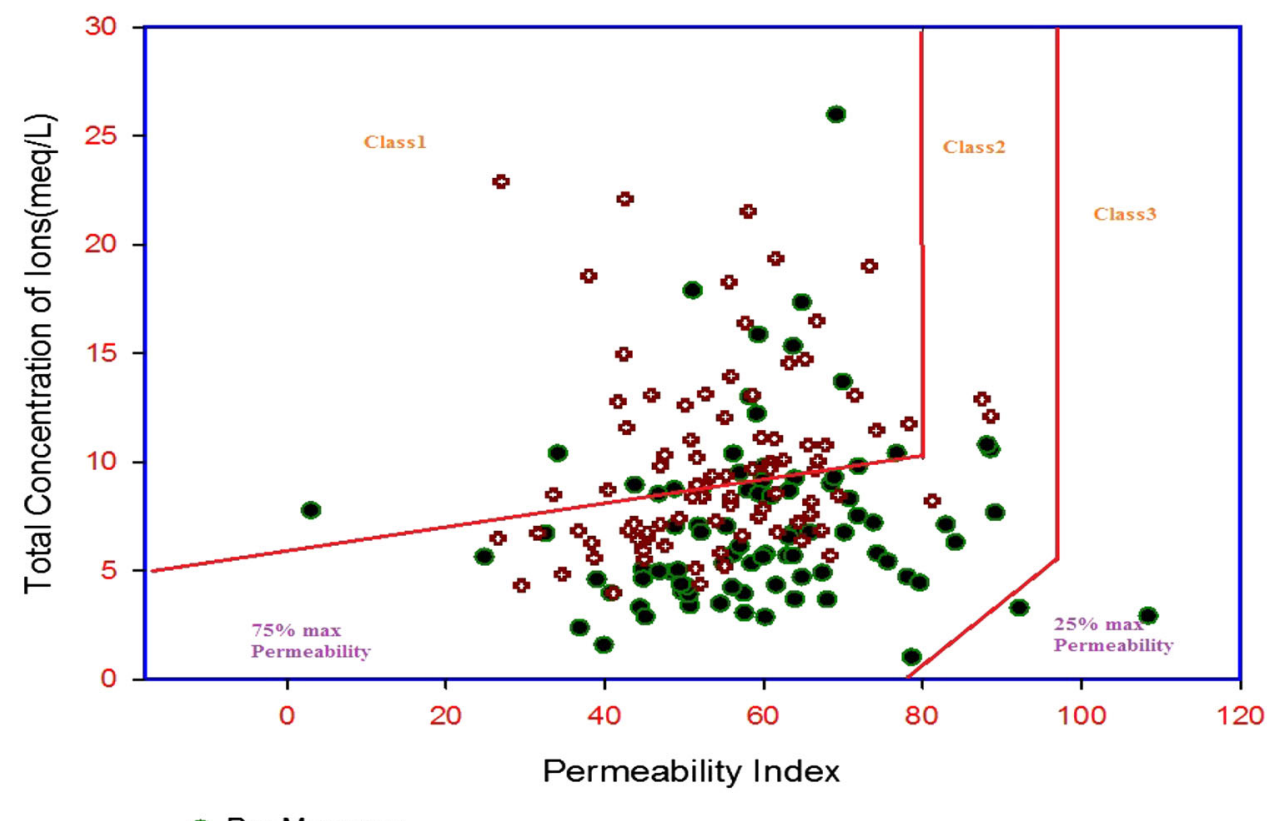

- Pre Monsoon

- Post Monsoon

\section{Permeability index}

The impact of long-term irrigation practices leads to reduction in permeability of soil. The ions such as $\mathrm{Na}^{+}$, $\mathrm{HCO}_{3}{ }^{-}, \mathrm{Ca}^{2+}$ and $\mathrm{Mg}^{2+}$ in groundwater influence the permeability of soil (Haritash et al. 2014; Gopinath et al. 2015; Chidambaram et al. 2011). Doneen classified the water for irrigation based on permeability index as shown in the Fig. 18. The permeability index is calculated using the following equation (Doneen 1962):

Permeability index $(\mathrm{PI})=\left\{\left(\mathrm{Na}+\sqrt{ } \mathrm{HCO}_{3}^{-}\right) /\right.$

$$
(\mathrm{Ca}+\mathrm{Mg}+\mathrm{Na})\} \times 100
$$

where the concentration of ions is expressed in meq/L. 


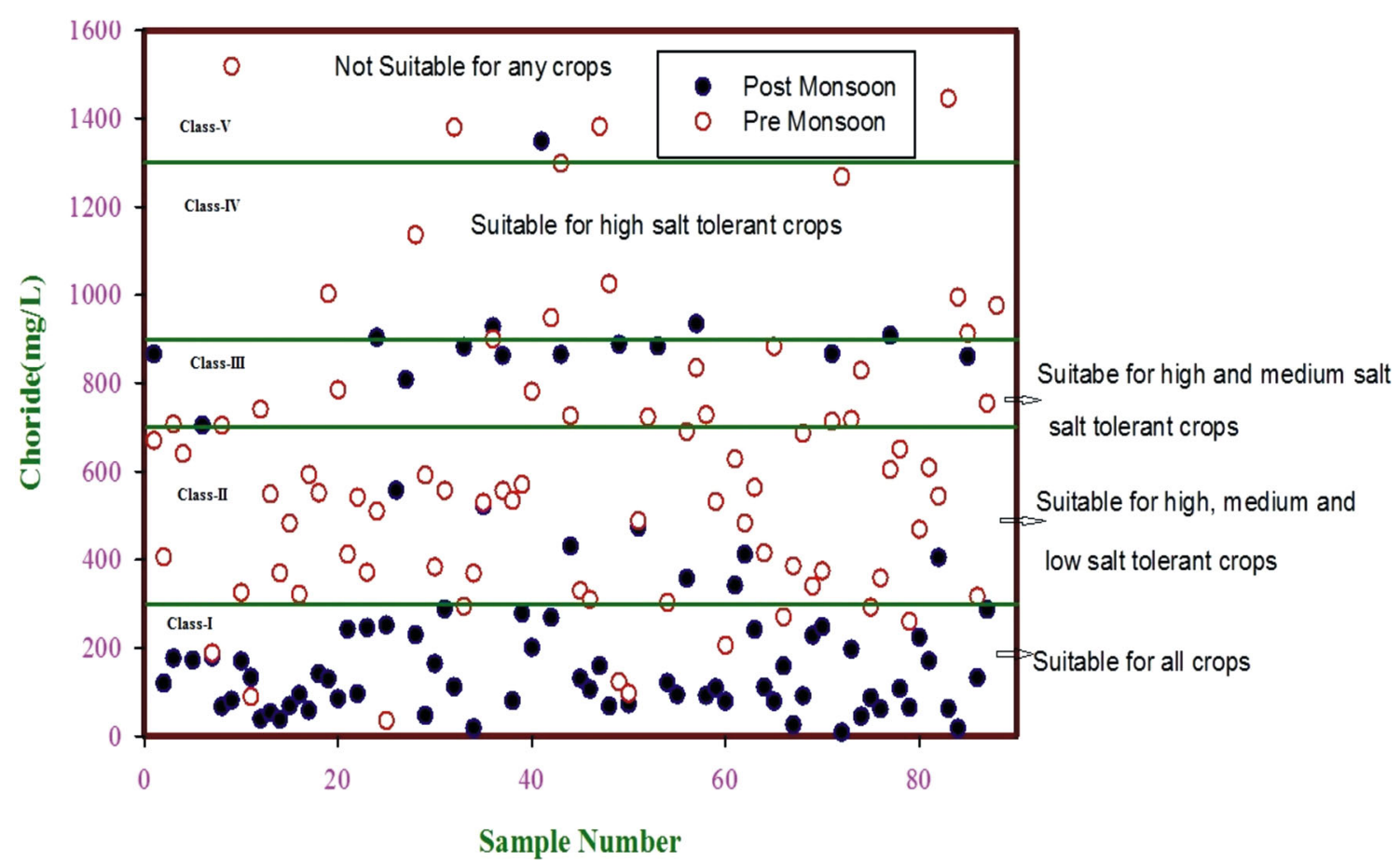

Fig. 19 Chlorinity index for water samples

In the study area, almost all the samples in post- and premonsoon fall under class 1 and class 2 indicating that water is moderately suitable to suitable for agricultural purposes. In pre-monsoon, $2.3 \%$ of samples fall in class 3 indicating that those samples are not suitable for agriculture purposes (Fig. 18). Kariamanickam, Lingareddipalayam, Soriyankuppam, Tavalakuppam, Thirubhuvanai, Tirukanur and Vadanur in pre-monsoon and Kakayantopu, Kotakuppam, and Pudukupam in post-monsoon are not suitable for agriculture.

\section{Magnesium adsorption ratio (MAR)}

In groundwater, there exists equilibrium between $\mathrm{Ca}$ and Mg. During equilibrium MAR makes the soil more alkaline, reducing the soil quality and crop yield (Paliwal 1972; Haritash et al. 2014). The MAR was calculated using the following expression:

MAR $=\mathrm{Mg} \times 100 /(\mathrm{Ca}+\mathrm{Mg})$

where the concentration of ions is expressed in meq/L.

Based on MAR, groundwater suitable for agriculture can be identified. If the MAR is $<50$ water is considered to be suitable and if MAR $>50$ water is unsuitable for agriculture purpose (Fig. 14a, b). In the study area, 90.9 and $97.8 \%$ of water samples in pre- and post-monsoon are suitable for agriculture whereas 9.1 and $2.2 \%$ of samples are not suitable for agriculture. Idayanchavadi,
Kariambattur, Mannadipet, Pondicherry white town in pre-monsoon and Pudukuppam, Tirukanur, Vanur and Palecherry in post-monsoon are the places having MAR greater than $50 \mathrm{meq} / \mathrm{L}$.

\section{Chlorinity index}

The concentration of chloride and its suitability for agriculture are shown in Fig. 19. High salt content in irrigation water is toxic to plants (Ramesh et al. 2012). Majority of samples in post-monsoon and pre-monsoon fall under class I, II and III (Fig. 19) indicating suitability for cultivation purposes.

\section{Temporal variation in quality of groundwater}

The coastal aquifers are much susceptible for contamination due to seawater intrusion, urbanization, population growth, etc. Water quality data already available for the year 2004 and 2008 were compared with those of the present study in 2014. The average rainfall of the study area is $1272.7 \mathrm{~mm}$ which was most deficient in the year 2014 followed by 2004 and 2008 (Table 7). The Electrical Conductivity, Total Dissolved Solids and concentration of ions like chloride, calcium, potassium, and magnesium were found to be increasing which indicates the deterioration of quality of groundwater with time (Fig. 20a, c, d). The degradation of water quality in the study area is 
Table 7 Groundwater quality data of pre-monsoon (PRM) and postmonsoon (POM) of year 2004, 2008 and 2014

\begin{tabular}{|c|c|c|c|c|c|c|}
\hline \multirow{2}{*}{$\begin{array}{l}\text { Year } \\
\text { Parameters }\end{array}$} & \multicolumn{2}{|l|}{2004} & \multicolumn{2}{|l|}{2008} & \multicolumn{2}{|l|}{2014} \\
\hline & POM & PRM & POM & PRM & POM & PRM \\
\hline $\mathrm{pH}$ & 8 & 7 & 7 & 7 & 6.44 & 7.03 \\
\hline $\mathrm{EC}$ & 684 & 839 & 777 & 719 & 1143 & 1187 \\
\hline TDS & 431 & 528 & 488 & 400 & 642 & 646 \\
\hline $\mathrm{Na}$ & 31 & 43 & 67.4 & 129 & 56 & 35 \\
\hline K & 24 & 2 & 9.4 & 4 & 64 & 49 \\
\hline $\mathrm{Ca}$ & 34 & 44 & 49 & 21 & 25 & 160 \\
\hline $\mathrm{Mg}$ & 25 & 26 & 23 & 72 & 27 & 76 \\
\hline $\mathrm{Cl}$ & 120 & 156 & 118 & 451 & 201 & 361 \\
\hline
\end{tabular}

attributed to tremendous increase in population, seawater intrusion, overpumping, urbanization and improper sewage disposal.

\section{Conclusion}

The quality of groundwater for domestic and agricultural purposes was studied along the coastal aquifers of Puducherry region. From the above study, it is inferred that the abundance of cations and anions was in the order of $\mathrm{Na}>\mathrm{Ca}>\mathrm{Mg}>\mathrm{K}=\mathrm{Cl}>\mathrm{SO}_{4}>\mathrm{HCO}_{3}$ in pre-monsoon and post-monsoon. The ions such as $\mathrm{Na}, \mathrm{Ca}, \mathrm{Cl}$ and $\mathrm{SO}_{4}$ in very few samples were higher than the permissible limit which may be due to seawater intrusion, mineral dissolution, intense agricultural practices and improper sewage disposal. The electrical conductivity and total dissolved solids of the water samples were permissible for drinking purposes. The hardness of the water samples was less than $75 \mathrm{mg} / \mathrm{L}$ indicating soft nature of groundwater. Altogether the groundwater is largely safe and suitable for drinking and domestic purposes except in few locations.
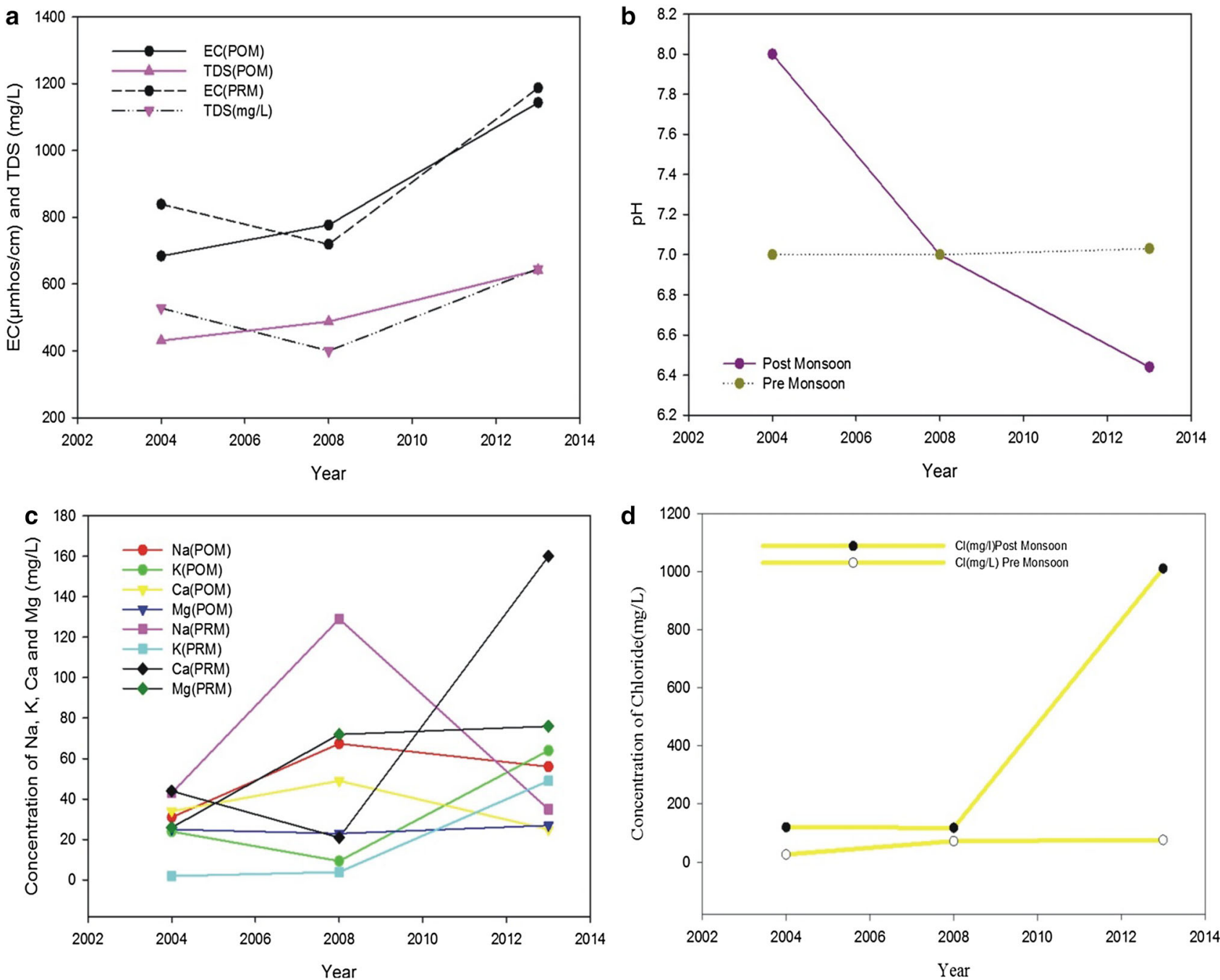

Fig. 20 a Temporal variation of groundwater EC and TDS, b temporal variation of groundwater $\mathrm{pH}, \mathbf{c}, \mathbf{d}$ temporal variation of ions Na, K, Ca and $\mathrm{Mg}$, during the pre-monsoon (PRM) and post-monsoon (POM) of the year 2004, 2008 and 2014 
The quality of groundwater for irrigation is analyzed by calculating parameters such as SAR, Na\%, PI, MAR and Chlorinity index which indicates that the majority of water samples are very good to moderately suitable for agriculture. About $5.7 \%$ of water samples show higher RSC indicates that the long-term use of such water may affect crop production and reduce soil quality. In SAR vs. Salinity hazard plot, majority of water samples fall under medium saline to low sodium type indicating that water is suitable for irrigation. Based on PI, it is found that groundwater is good to moderately suitable for agriculture and there is no much threatening of reduction in permeability of soil. As a whole, the quality of groundwater is suitable for agriculture purpose. The temporal variation of groundwater quality depicts that there is a significant increase in $\mathrm{EC}$, TDS and ions like $\mathrm{Mg}, \mathrm{K}, \mathrm{Ca}$ and $\mathrm{Cl}$ chiefly due to anthropogenic activities with little geogenic impact. Hence, the present study recommends that regular monitoring of groundwater is essential to avoid major environmental threat.

Acknowledgements We thank the funding agency University Grants Commission (F.No.41-1035/2012(SR);Date: 23.07.2012) through major research project. Also we would extend our sincere thanks to Department of Earth Sciences, Department of Ecology and Environmental Sciences and Central Instrumentation Facility of Pondicherry University for providing facilities for analysis. In addition, we would like to thank Water Testing Laboratory, Public Health Division (PWD), Puducherry. In addition, we extend our thanks to the editor and anonymous reviewer for their positive, valuable and effective opinion for bringing this research paper to this level.

Open Access This article is distributed under the terms of the Creative Commons Attribution 4.0 International License (http:// creativecommons.org/licenses/by/4.0/), which permits unrestricted use, distribution, and reproduction in any medium, provided you give appropriate credit to the original author(s) and the source, provide a link to the Creative Commons license, and indicate if changes were made.

\section{References}

Annapoorna H, Janardhana MR (2015) Assessment of groundwater quality for drinking purpose in rural areas surrounding a defunct copper mine. Aquatic Procedia 4:685-692. doi:10.1016/j.aqpro. 2015.02.088

Basavarajappa HT, Manjunatha MC (2015) Groundwater quality analysis in precambrian rocks of chitradurga district, karnataka, india using geo-informatics Technique. Aquatic Procedia 4:1354-1365. doi:10.1016/j.aqpro.2015.02.176

Batayneh A, Zaman H, Zumlot T, Ghrefat H, Mogren S, Nazzal Y, Al-Taani A (2014) Hydrochemical facies and ionic ratios of the coastal groundwater aquifer of Saudi Gulf of Aqaba: implication for seawater intrusion. J Coastal Res 293:75-87. doi:10.2112/ jcoastres-d-13-00021.1

Brindha K, Elango L (2011) Hydrochemical characteristics of groundwater for domestic and irrigation purposes in
Madhuranthakam, Tamil Nadu, India. Earth Sci Res J 15(2):101-108. ISSN 1794-6190

Bureau of Indian Standards (BIS) (2012) Indian standard drinking water specification (second revision) BIS 10500:2012, New Delhi

Central Ground Water Board (CGWB) (2007) Groundwater Brochure of Puducherry Region U.T of Puducherry, pp 1-27. http://www. cgwb.gov.in/District_Profile/Puduchery/Puducherry.pdf

Chidambaram S, Karmegam U, Prasanna MV, Sasidhar P, Vasanthavigar M (2011) A study on hydrochemical elucidation of coastal groundwater in and around Kalpakkam region, Southern India. Environ Earth Sci 64(5):1419-1431. doi:10.1007/s12665011-0966-3

Das S, Nag SK (2015) Deciphering groundwater quality for irrigation and domestic purposes-a case study in Suri I and II blocks, Birbhum District, West Bengal, India. J Earth Syst Sci 124(5):965-992. doi:10.1007/s12040-015-0583-8

Davis SN, DeWiest RJ (1966) Hydrogeology. Wiley, New York

Doneen LD (1962) The influence of crop and soil on percolating water. In Proc. 1961 Biennial conference on Groundwater recharge, pp 156-163

Eaton FM (1950) Significance of carbonates in irrigation waters. Soil Sci 69(2):123-134. doi:10.1097/00010694-195002000-00004

El Tahlawi MR, Abo-El Kassem M, Baghdadi GY, Saleem HA (2016) Estimating and plotting of groundwater quality using WQIUA and GIS in Assiut Governorate, Egypt. World J Eng Technol 4:59-70. doi:10.4236/wjet.2016.41007

Gopinath S, Srinivasamoorthy K, Saravanan K, Prakash R, Suma CS, Khan F, Senthilnathan D, Sarma VS, Devi P (2015) Hydrogeochemical characteristics of coastal groundwater in Nagapattinam and Karaikal aquifers: implications for saline intrusion and agricultural suitability. Coast Sci J, figshare. doi:10.6084/ m9.figshare.1512790.v1

Haritash AK, Gaur S, Garg S (2014) Assessment of water quality and suitability analysis of River Ganga in Rishikesh. Appl Water Sci, India. doi:10.1007/s13201-014-0235-1

Hem JD (1985) Study and interpretation of the chemical characteristics of natural water (Vol. 2254). Department of the Interior, US Geological Survey

Herman B (1978) Groundwater Quality. Groundwater Hydrology, Mc.Graw-Hill, Kogakusha Ltd., Tokyo, pp 339-375

Iqbal H, Inam A, Bakhtiyar Y, Inam A (2012) Effluent quality parameters for safe use in agriculture. Water Qual Soil Manag Irrig Crops. doi:10.5772/31557

John HH, Dickerson JWT (1993) American Public Health Association (APHA), 120th Annual Meeting, Washington, DC. J R Soc Promot Health 113(1):47-47. doi:10.1177/1466424093113 00112

Kazemi GA, Mohammadi A (2012) Significance of hydrogeochemical analysis in the management of groundwater resources: a case study in Northeastern Iran. Hydrogeol A Global Perspect. doi:10. $5772 / 39214$

Krishna Kumar S, Chandrasekar N, Seralathan P, Godson PS, Magesh NS (2011) Hydrogeochemical study of shallow carbonate aquifers, Rameswaram Island, India. Environ Monit Assess 184(7):4127-4138. doi:10.1007/s10661-011-2249-6

Kumar KSA, Priju CP, Prasad NBN (2015) Study on Saline Water Intrusion into the Shallow Coastal Aquifers of Periyar River Basin, Kerala Using Hydrochemical and Electrical Resistivity Methods. Aquatic Procedia 4:32-40. doi:10.1016/j.aqpro.2015. 02.006

Mondal NC, Singh VP, Singh VS, Saxena VK (2010) Determining the interaction between groundwater and saline water through groundwater major ions chemistry. J Hydrol 388(1-2):100 111. doi:10.1016/j.jhydrol.2010.04.032 
Nag SK, Lahiri A (2012) Hydrochemical characteristics of groundwater for domestic and irrigation purposes in Dwarakeswar watershed area, India. Am J Clim Change 01(04):217-230. doi:10.4236/ajcc.2012.14019

Nathan DS, Kumar RM, Reddy SS, Sivasankaran MA, Ramesh R (2012) Trace elements in groundwater of coastal aquifers of Pondicherry Region, India. J Environ 1(04):111-118

Nwankwoala H, Eludoyin O, Obafemi A (2012) Groundwater quality assessment and monitoring using geographic information systems (GIS) in Port Harcourt, Nigeria. Ethiop J Environ Stud Manag. doi:10.4314/ejesm.v5i4.s19

Paliwal KV (1972) Irrigation with saline water. IARI Monograph no 2 (New series), New Delhi, p 198

Pethaperumal S, Chidambaram S, Vijayaragavan K, Prasanna MV, Anandavel K, Karmegam U, Tirumalesh K (2010) A novel approach for groundwater budgeting using GIS in a Part of Pondicherry Region, India. J Water Resour Protection 02(06):585-591. doi:10.4236/jwarp.2010.26067

Ramesh K, Elango L (2011) Groundwater quality and its suitability for domestic and agricultural use in Tondiar river basin, Tamil Nadu, India. Environ Monit Assess 184(6):3887-3899. doi:10. 1007/s10661-011-2231-3

Ramesh K, Bhuvana JP, Li T (2012) Hydrochemical characteristics of groundwater for domestic and irrigation purposes in Periyakulam Taluk of Theni District, Tamil Nadu. I Res J Environ Sci 1:19-27

Richards LA (1954) Diagnosis and improvement of saline and alkali soils. Soil Sci 78(2):154. doi:10.1097/00010694-19540800000012

Sarath Prasanth SV, Magesh NS, Jitheshlal KV, Chandrasekar N, Gangadhar K (2012) Evaluation of groundwater quality and its suitability for drinking and agricultural use in the coastal stretch of Alappuzha District, Kerala, India. Appl Water Sci 2(3):165-175. doi:10.1007/s13201-012-0042-5

Sawyer GN, McCarty DL (1967) Chemistry of sanitary engineers, 2nd edn. McGraw Hill, New York, p 518

Senthilkumar S, Balasubramanian N, Gowtham B, Lawrence JF (2014) Geochemical signatures of groundwater in the coastal aquifers of Thiruvallur district, south India. Appl Water Sci. doi:10.1007/s13201-014-0242-2

Sheikhy Narany T, Ramli MF, Aris AZ, Sulaiman WNA, Juahir H, Fakharian K (2014) Identification of the hydrogeochemical processes in groundwater using classic integrated geochemical methods and geostatistical techniques, in amol-babol plain, Iran. Sci World J 2014:1-15. doi:10.1155/2014/419058

Subba Rao N (2001) Geochemistry of groundwater in parts of Guntur district, Andhra Pradesh, India. Env Geol 41(5):552-562. doi:10. 1007/s002540100431

Thilagavathi R, Chidambaram S, Prasanna MV, Thivya C, Singaraja C (2012) A study on groundwater geochemistry and water quality in layered aquifers system of Pondicherry region, southeast India. Appl Water Sci 2(4):253-269. doi:10.1007/ s13201-012-0045-2

Todd DK (1980) Groundwater hydrology (2nd ed., p 315). New York: Wiley 31

Wilcox LV (1955) Classification and use of irrigation waters, USDA, circular 969, Washington DC, USA

World Health Organization (2004) Guidelines for drinking-water quality: recommendations (Vol. 1). World Health Organization 